Portland State University

PDXScholar

Dissertations and Theses

Dissertations and Theses

6-9-1974

Partisan Voting in the Oregon Legislature

Tom Lee Mason

Portland State University

Follow this and additional works at: https://pdxscholar.library.pdx.edu/open_access_etds

Part of the American Politics Commons

Let us know how access to this document benefits you.

Recommended Citation

Mason, Tom Lee, "Partisan Voting in the Oregon Legislature" (1974). Dissertations and Theses. Paper 1981.

https://doi.org/10.15760/etd.1980

This Thesis is brought to you for free and open access. It has been accepted for inclusion in Dissertations and Theses by an authorized administrator of PDXScholar. Please contact us if we can make this document more accessible: pdxscholar@pdx.edu. 
AN ABSTRACT OF THE THESIS OF Tom Lee Mason for the Master of Science presented July 9, 1974.

Title: Partisan Voting in the Oregon Iegislature.

APPROVED BY MEMBERS OF THE THESIS COMMITTEE:
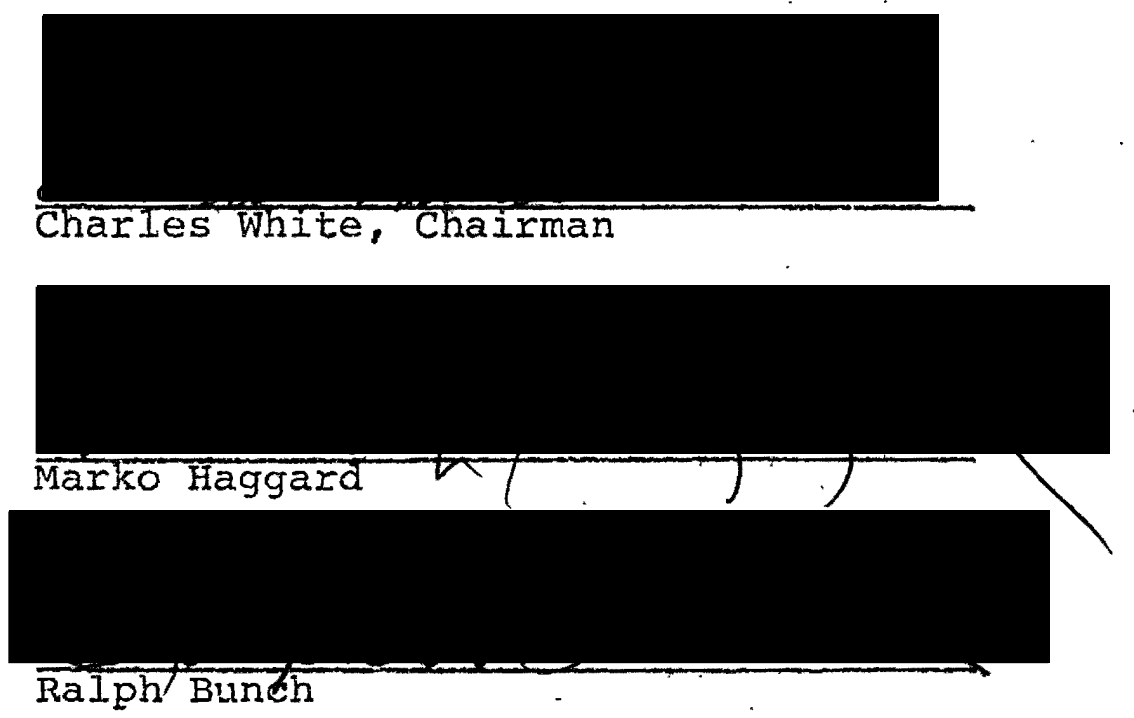

The thesis examines the role of partisanship in two sessions of the Oregon Legislature. Both the Oregon Senate and the Oregon House of Representatives were examined for the 56th (1971) and the 57th (1973) session. Indicies of partisanship, or party cohesion were developed for both parties in both houses during both sessions. Each legislator was also assigned an index of partisanship. The indicies of partjsanship for 
the parties were the average percentage of the members of the two parties voting together on those issues which. underwent "party votes." A party vote was defined as any vote on which the majority of one party was opposed by at least the majority of the other party. The individual index of partisanship for each legislator was that percentage of time the legislator was on the same side as the majority of his or her party during party votes. These two indicies, of party partisanship and individual partisanship allowed comparison of the parties themselves and various subgroups within the parties such as urban legislators, legislators under thirty years of age and women legislators. All calculation was done by means of a special program on an IBM 1130 computer. 
PARTISAN VOTING IN THE OREGON LEGISIATTURE

by -

TOM LEE MASON

A thesis submitted in partial fulfillment of the requirements for the degree of

MASTER OF SCIENCE

in

POIJTICAL SCIENCE

Portland State University

1974 
TO THE OFFICE OF GRADUATE STUDIES AND RESEARCH:

The members of the committee approve the thesis of Tom Lee Mason, presented June 9, 1974.
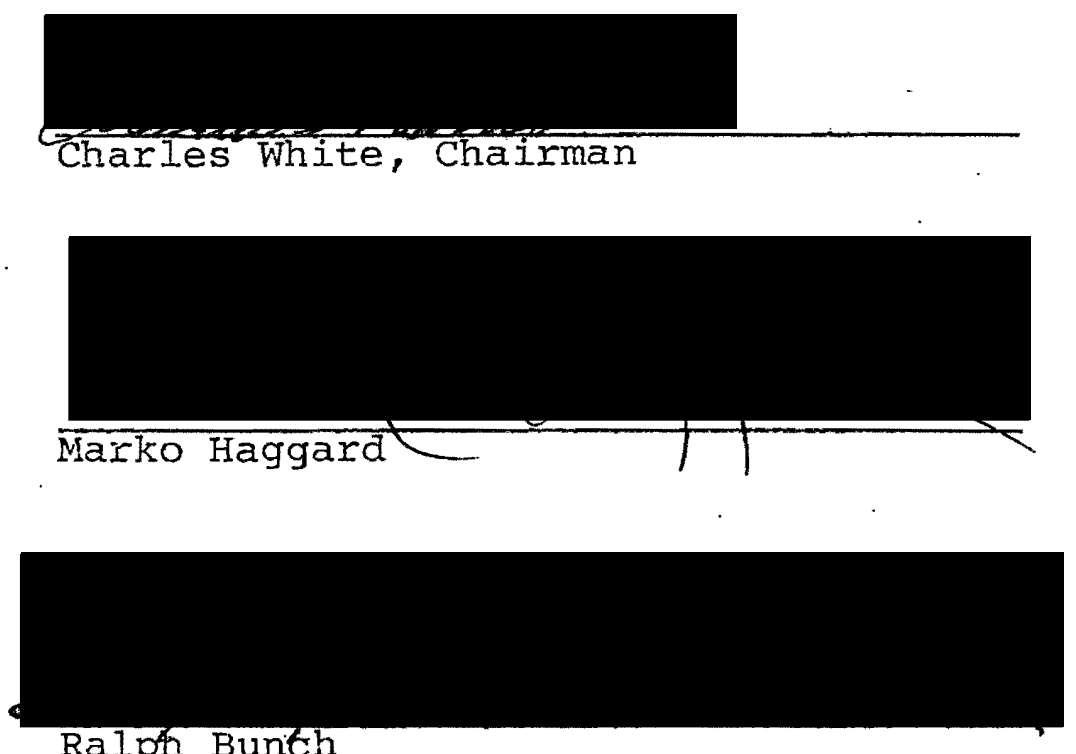

Ralph Bunth

APPROVED:

Norman Greene, Head Department of Political Science

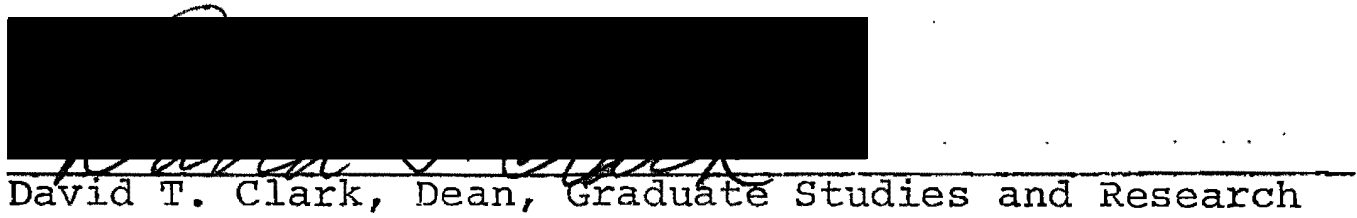

June , 1974. 


\section{IN APPRECIATION}

I wish to thank:

Dary She11

Nancy Chafin

Charles White 
PAGE

ACKNOWLEDGMENTS

iii

IIST OF TABLES $\ldots \ldots \ldots \ldots \ldots \ldots \ldots \ldots \ldots \ldots \ldots \ldots \ldots$ iv

IIST OF FIGURES ..................... vii

CHAPTER

I INTRODUCTION.................. 1

Analysis of Roll Call voting..... 2

II DESCRIPTION OF THE PROBLEM.......... 10

Party Votes................. I0

Areas of Inquiry.............. 12

III THE $56 \mathrm{TH}$ SESSION.............. 15

General Description of Session... 15

The senate................. 16

The House................... 23

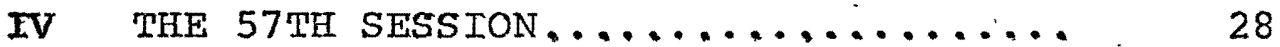

General Description of the Session 28

The senate................. 29

The House................. 32

V AREAS OF INDUIRY ................. 42

The Two Major Parties.......... 42

Urban Legislators............ 44

Women Iegislatoxs............ 48 
CHAPTER

PAGE

Legislators Under Thirty........ . 49

Freshmen Legislators.......... 51

Change in Partisanship Due to

Election From a single

Member District............ 52

VI CONCLUSIONS ....................... 55

BIBLTOGRAPHY ........................ 60 


\section{LIST OF TABLES}

TABIE

PAGE

I Comparison of Rarty Cohesion for the

Democratic and Republican Parties

in the 56th Session of the Oregon

senate......................

II Individual Indices of Partisanship for

Senators in the 56th Session.

Percentage Each Legislator Voted

with His or Her Own Party on Party

Votes.......................

II Comparison of Party Cohesion for the

Democratic and Republican Parties

in the 56th Session of the Oregon

House of Representatives.

IV Individual Indices of Partisanship for

Representatives in the 56 th session.

Percentage Each Legislator Voted with

His or Her own Party.

V Comparison of Party Cohesion for the

Democratic and Republican Parties

for the 57th Session of the oregon

Senate....................... 
VI Individual Indices of Partisanship for

Senators in the 57 th Session. Percentage Each Iegislator Voted with His ox Her

Party on Party Votes...............

VII Comparison of Party Cohesion for the

Democratic and Republican Parties in the 57 th Session of the Oregon House

of Representatives .................

VIIT Individual Indices of Partisanship for

Representatives in the 57 th Session.

Percentage Each Legislator Voted with

His or Her Party on Party Votes.......

Ix Comparison of Cohesion of the Two Parties

Over Both Sessions in Both Houses.....

$x$ Indices of Partisanship for Urban

Legislators in the $57 t h$ Session......

XI Partisanship of Women Legislators for

the $57 t h$ session................

XI Partisanship of Legislators Under

Thirty Years of Age for the 57 th

session .....................

XIII Partisanship of Freshmen Legislators

for the $57 t h$ Session.............. 
XIV Comparison of Partisanship of

Legislators Representing Multimember Districts in the 56 th

Session and Single Member Districts

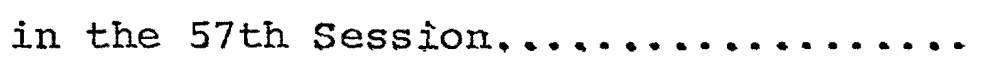




\section{LIST OF FIGURES}

FIGURE

PAGE

1 Graph Placing Democratic Senators in

Rank Order Relationship........ 21

2 Graph Placing Republican Senators in

Rank Order Relationship........ 22

3 Graph Placing Democratic Representa-

tives in Rank Order Relationship.. 26

4 Graph Placing Republican Representa-

tives in Rank Order Relationship..

5 Graph Placing Democratic Senators in

Rank Order Relationship

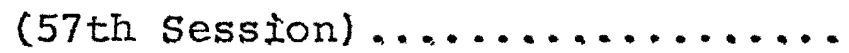

6 Graph Placing Republican Senators in

Rank Order Relationship

(57th Sessionl............... 34

7 Graph Placing Democratic Representa-

tives in Rank order Relationship

(57th session) ............... 39

8 Graph Placing Republican Representa-

tives in Rank Order Relationship

(57th Session).............. 40 
CHAPTER I

\section{INTRODUCTION}

The purpose of this study is to examine the relation between partisanship and roll call voting in the 57 th session of the Oregon Legislature. Many of the conclusions and findings relate to what could be called the "folk wisdom" of oregon politics. It is nothing new or profound, for example, to say that urban Republican legislators tend to vote with Democratic legislators, or that rural Democratic legislators tend to vote with Republicans. It is, however, useful to be able to state the above relationships. in quantified terms which confirm or deny that "folk wisdom". An examination of these relationships should also shed light on the nature of the legislative process in Oregon.

Three fundamental changes occurred between the 56 th and 57 th sessions of the Oregon Legislature. First, the Oregon Senate came under Democratic control for the first time in its history. It had previously been under the control of either the Republicans or a coalition of Republicans and conservative Democrats. 1 Second, the Oregon House of Representatives came under Democratic control for the first time since 1961. Finally, all members of the 57 th session were elected from single member districts. Urban legislators had previously been elected at large.

1 Although the word "conservative" is an ambiguous term, it is probably the one most descriptive and available to describe those particular individuals. 
The effects of these three changes will be examined throughout this paper in relation to partisan voting patterns of both the parties as wholes and the individual legislators.

\section{Analysis of Roll Call Voting}

"The recorded decisions of legislative bodies provide valuabie information about the political systems at large in which they function."2 This statement by Duncan MacRae . is an apt and succinct rationale for the study of roll call. voting. Such studies do, by their very nature, contribute information about the political system as a whole. The study of a specific organ of the body gives information on the nature of the body itself. The specific organ in this study is one of the fifty state legislatures, a small organ in an infinitely complex body, the body politic.

Conclusions reached by analysis of roll call voting must be tempered with a knowledge of the legislative process, however. In the Oregon Legislature, work performed in comittee is a major part of the process. Analysis of roll call voting is not a methodological panacea for ali possible questions.

Much of the interaction which takes place during the legislative process is unmeasurable by present methods of quantification. The decisions reached by a legislative

2 Duncan MacRae, Issues and Parties in Legislative Voting (New York: Harper and Row, 1970), p. T. 
body are the result of a complex process of interaction containing elements of which we are only partially aware. One element which we are aware of is partisanship. Specifically, partisanship is any one legislator's attitude or disposition toward the party to which he or she belongs. Restated, it is the legislator's perception of party membership. Every Oregon legislator claims to belong tọ a political party and every legislator has some conception of what that entails. For some, it is mere registration under a label; for others, it is an active, compelling duty. This is literally the spectrum of possibilities as far as partisanship is concerned.

The roll call. votes held in a legislative body can be viewed as a constant series of questions being answered by the legislators. 3 Each vote requires a response from the legislator. The "yes" or "no" vote (and also an absent vote, in Oregon) is an answer to the question asked. The questions or votes can be seen as highly relevant indicators of the political attitudes held by those individuals. Again, partisanship is one of those attitudes. While these indices are not the actual attitude, they are both $a$ measure of it and, because they are derived from actual votes, a direct manifestation of it. In another sense, the

3 John G. Grumm, "A Factor Analysis of Legislative Behavior," Midwest Journal of Political Science, No. 7 (november, T963), p. 336. 
roll call vote can be seen as almost a real-life operational definition of partisanship. The main purpose in the present study is to use these indices in a comparison of groups which verifies or refutes popular hypotheses about Oregon politics in reference to partisanship.

Four major studies stand out in the field of roll call voting analysis; Lawrence Lowell's "The Influence of Party Upon Legislation in England and America," Julius Turner's Party and Constituency: Pressures on Congress, David Truman's The Congressional Party, and Duncan MacRae's Dimensions of Congressional Voting.

Lawrence Lowell's 1901. work, "The Influence of Party Upon Legislation in England and America, "4 was a landmark event in the study of legislative behavior. His. was the first major study of roll call voting. Lowell only examined those roll call votes during which $90 \%$ of the party memberships were on opposing sides. This, for a period, became the standard definition of a "party vote."

Lowell found that parties in America had comparatively little effect on legislation when contrasted with parties in Great Britain. He also found that the amount of party. voting varied from session to session. Lowell found no apparent reason for this variation.

4 Lawrence A. Lowell, "The Influence of Party Upon Legislation in England and America," Annual Report of the

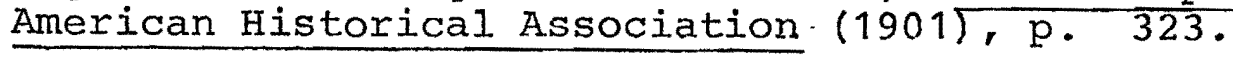


Although innovative in this work, Lowell did not choose to examine those party votes he discovered. He did not control for factors other than party, such as geographical region or constituency characteristics. He also did not identify any factors which might help explain why particular legislators deviated from their parties on party votes.

In 1951, Julius Turner published his Party and Constituency: Pressures on Congress. Turner used Lowell's 90\% definition of a party vote and found that between 1921 and 1948, only $17 \%$ of the roll call votes in the $U$. S. House of Representatives met this criterion. Turner did conclude, however, that party was the most clearly discernible factor in explaining why votes were cast. He reached this conclusion because he found that party made a significant difference in $90 \%$ of the votes he examined. Because of this difference Turner also concluded that American political parties were much more responsible than many people had supposed them to be. 5

In a later revised edition of Turner's work, the threshold level was lowered to $50 \%$. 6 This was done to include more data than found in the previous study.

5 Julius Turner, Party and Constituency: Pressures on Congress (Baltimore: John Hopkins Press, 1951), p. 23.

6 Julius Turner, Party and Constituency: Pressures on Congress, rev. ed., Edward Schneier, editor (Baltimore: John Hopkins Press, 1970), cited in William Keefe and Morris ogul's The Iegislative Process (Englewood Cliffs, N. J.: PrenticeHall, 1972), p. 301 . 
Another major work in the analysis of roll call voting is The Congressional Party by David Truman. Truman's work was extensive and combined statistical analysis of voting patterns with a discussion of the role of legislative leadership. Truman used a cluster-bloc analysis technique which measures the agreement of each legislator with every ather legislator. He was able to identify certain blocs and he explored the natures of those blocs. On different issues, Truman found the parties split into different blocs. For example, he found an East-West split in the Senate Dernocrats on international issues. 7 In reference to partisanship, Truman found that the Democrats were more cohesive than the Republicans during the 81st Session of the U. S. Congress which he studied. 8

From the standpoint of statistics and quantified data, Duncan MacRae's Dimensions of Congressional Voting is the outstanding work. Among other techniques, MacRae uses Guttman scaling. Guttman scaling is a cumulative technique which relates similar responses. Scales are constructed for both parties. These include a Fair Deal scale and an Agriculture Scale. MacRae cross tabulates scores on the various scales with constituency characteristics. He finds

7 David B. Truman, The Congressional Party (New York: John Wiley and Sons, 1959), p. 82 .

8 Truman, p. 82. 
that rural Democrats tend to be more conservative than urban Democrats on the Fair Deal Scale, but he points out that Southern Democrats tend to be more conservative regardless of their constituencies. ${ }^{9}$ Rural or farm Republicans, in addition, are more conservative than urban Republicans. 10 MacRae also did an analysis of roll call voting in the Massachusetts House of Representatives using factor analysis. 11 Republican representatives in Massachusetts tended to come from rural or suburban upper class areas. Democrats, on the other hand, tended to come from urban lower class areas. MacRae wanted to measure the relation of constituency to voting in those districts which had close elections. MacRae defined a "close" election as an instance in which the winner obtained less than $60 \%$ of the vote. He then selected seven issues on which the parties found themselves in opposition.

MacRae found the greatest amount of deviation (an individual voting against the majority of his or her party) on the part of representatives elected from districts atypical of their own party and typical of the opposing party. In other words, deviant Democrats tended to come from Repub-.

9 Duncan MacRae, Jr., Dimensions of Congressional Voting (Berkeley: University of California Press, 1958), p. 261 .

10 MacRae, Dimensions, p. 263.

11 Duncan MacRae, Jr., "The Relation Between Roll CaII Votes and Constituencies in the Massachusetts House of Representatives," American Political Science Review, No. 4 (December, 1952), pp. 1046-1055. 
lican like districts and vice versa. ${ }^{12}$ Mackae observed that the party regulars, those who deviated from the majority the least, came from districts with wide electoral margins. MacRae could be criticized for using only seven roll call votes.

John Grumm also used factor analysis to examine roll call voting in a state legislature. Grumm examined the Kansas legislature in 1957 and 1959, using a 65\% threshold level to define a party vote. He found 41 House issues and 57 senate issues which had party votes. 13 Correlation matrices were constructed for each house; then coefficients were computed. Grumm found that the presence of a large number of Democratic voters or urban workers in a Republican senator's district tended to be correlated with that senator's voting with the Democrats. ${ }^{14}$ Grumm also found a high correlation between the Democratic factors and the "liberal" factors. 15 A liberal legislator, according to Grumm's definition, was one who was willing to vote for such things as social programs, welfare increases, and increases in salaries for government employees.

12 MacRae, "The Relation Between Roll Call Votes and. Constituencies," p. 1051.

13 Grumm, p. 341.

14 Grumm, p. 347.

15 Grumm, p. 351. 
In addition to party being an important factor, Grumm found two other factors important in their effect on voting: whether a district was urban or rural, and whether a district was growing or declining in population.16 Grumm found that senators from growing areas tended to be conservative, while senators from declining areas tended to be liberal. 17

Most of the findings of these various studies are fairly consistent. Constituency and party influence are constant themes throughout the literature of roll call voting analysis, and appropriately so. The important question asked by examination of party and constituency influences is, simply, "Who are the legislators representing?" Much of the time it is hard to separate the two factors. Does a particular legislator vote a certain way because he is a Democrat or because he is from an urban area? Most of what was discovered in the following study of the oregon Legislature was consistent with earlier studies. It was decided to go beyond the factors of party and constituency into other areas which are perhaps of equal or even more importance. This will be discussed in detail in the next. chapter.

16 Grumm, p. 350.
17 Grumm, p. 351. 
DESCRIPTION OF THE PROBLEM PARTY VOTES

Before the amount of partisanship can be measured, a definition of what constitutes a "party vote" has to be asserted. Iowe11's use of 90\% opposing majorities has been mentioned. This was a very rigorous standard and tended to eliminate data. The eliminated data, of course, were the bills on which there were less than $90 \%$ opposing majorities or no opposing majorities at al1. If Lowell's $90 \%$ threshola is used, the only comparison which can be made between two parties would be from the $90 \%$ level to the $100 \%$ level. This would obviously be inadequate. For this study, the standard of the Congressional Quarterly was used. ${ }^{18}$. Any roll call vote which has the majorities. (55\% to insure whole vote divisions) of the two parties on opposing sides will be considered a party vote.

The oregon Constitution requires an absolute majority of those legislators elected to pass any measure. This

18 "Party Unity Voting: Sharp Decline in 1972 Session," Congressional Roll Call (Washington, D. C. Congressional Quarterly, Inc., 1973), p. 2122.

Congressional Quarterly periodically reports on party voting in the U.S. Congress using the above mentioned method. In the 1972 Session C. Q. Found that $36 \%$ of the roll call votes in the House and $27 \%$ of the roll call votes in the senate were party votes. In the House, the Democrats had an average partisan score of $58 \%$ while the Republicans had an average score of 66\%. The House Democrats won 52\% of the party votes, with the Republicans winning the other $48 \%$. In the Senate theDemocrats had an average partisan score of $57 \%$. The Republicans had an average of $66 \%$. The Senate Democrats won $56 \%$ of the party votes, with the senate Republicans winning $44 \%$. 
effectively means that excused or absent members cast "no" votes. In the collection of data, absent or excused votes were considered "no" votes. There are no "tie" votes. A motion receiving an equal number of yes and no votes fails; thus, the party voting "no" wins the motion. The study eventually included examination of approximately three thousand bills in both the 56 th and 57 th sessions. Both third reading and procedural votes were considered. Procedural votes include such motions as, to table a bill or to refer a bill back to committee. Procedural questions are common points of partisan conflict. The respective party members are supposed to vote with their own parties on procedural votes. Third reading votes, of course, are votes on final passage in a particular house. once al1 party votes were identified, percentages of party cohesion were computed for the two parties in each house for the two sessions. These percentages are the mean proportion of the number of party members voting together on party votes--or restated in simpler terms, the average percentage of the party members voting together on party votes. These percentages are the indices of party cohesion. Cohesion is a measure of the partisanship of the party as a whole. (The percentages always exceed 50\% because the definition of a party vote allows consideration of only those votes on which the majorities of the parties were on opposing sides.) 
Individual legislators were then assigned percentage indices of partisanship. These percentages are the proportions of the times they each voted with the majorities of their respective parties on party votes. 19

All three processes, identification of party votes, calculation of party cohesion indices, and calculation indices of individual partisanship, were done with an IBM 1130 computer.

To reiterate an earlier point, the indices of partisanship reported here are indicators of a particular political attitude. The endeavor here is the comparison of groups and individuals in reference to that attitude.

Areas of Inquiry

There were six areas of inquiry for this study.

1. The two major parties. How did the partisanship compare? Which of the two parties was the more partisan during the periods of study? The folk wisdom of Oregon politics says that the Republicans in the legislature are the more partisan; does this hold true?

19 Another popular index of cohesion is that of Stuart A. Rice. The Rice index of cohesion is the absolute difference between the percentage of those voting for an issue and those voting against an issue. For example, if $40 \%$ of a party voted "yes" and $60 \%$ voted "no" on an issue, the index of cohesion would be 20 . The Rice index does not necessarily assume that the parties are opposed on the particular issues which are examined. The Congressional Quarterly method used in this study has the distinct advantage of being readily. understandable to those not overly familiax with the quantitative methods of social science. 
2. Urban legislators. Do urban legislators differ from other legislators? What is the relation between partisanship and election from an urban district? The folk wisdom has it that urban Republicans vote with the Democrats a substantial proportion of the time; is this true?

3. Women legislators. More women are participating in politics. Do women differ from other legislators as a whole? The folk wisdom is that women are more "Iiberal." What can be said about this by looking at the partisanship of women legislators?

4. Legislators under thirty. There were eleven legislators under the age of thirty in the 57th session of the Oregon House. Young elected officials are usually thought to be more "liberal." Is this reflected in their partisanship?

5. Freshmen legislators. There were twenty-six freshmen legislators in the 57 th session. These freshmen were an unknown quantity before the session. How partisan were the new members?

6. Legislators representing single member districts. As mentioned earlier, there was a basic change between the 56 th and 57 th sessions in reference to single member districts. Some legislators who were elected from multimember districts in the 56 th session were elected from single member districts in the 57 th session. It was the popular belief that these individuals would be influenced by this change. Was there a change in partisanship for these people? 
Three of these areas of inquiry are variations upon the earlier mentioned theme of constituency and party influence: the major parties themselves, urban districts, and election from single member districts. The other areas of inquiry, such as women, youth and freshman status, are not constituency related factors. (In oregon there is, however, a high correlation between being a woman legislator and being from an urban district.) It is probably due to the lack of obvious constituency relation that these factors were not examined by the previous studies. As mentioned previously, they are elements in the oregon legislative process and should merit consideration.

If the nonconstituency related factors prove to be significantly related to partisanship, this would, to an extent, confirm the complex nature of the legislative process.

The 56th session was examined first to serve as a basis of comparison in several of these areas. The partisanship of the two parties under different leadership situations and the partisanship of legislators elected from single member districts were the factors which necessitated this. The other subgroups-urban legislators, women legislators, young legislators and freshmen legislators--were examined for the 57 th session only. 
General Description of the Session

Several major innovative pieces of legislation were passed by the 56th Session of the oregon Iegislature.

These included, among others:

SB 40 - Completely revised the criminal code.

SB 683 - Created the Children's Services Division.

HB 1036 - Outlawed no deposit bottles: the "Bottle Bi11."

HB 1054 - Allowed for consolidation of the City of Portland and Multnomah County.

HB 1059 - Created the state Department of Human Resources.

HB 1639 - Gave limited property tax relief to low income home owners.

HB 3037 - Expanded consumer protection Iaws. Only two of these major bills underwent party votes. HB 1054, City-County consolidation for Portland and Multnomah County, underwent a party vote on a procedural question in the senate. The minority report was defeated by the . Democrats, 17 to 13. In the House, HB 1639, the bill for property tax relief, also underwent a party vote on a procedural question. The minority report was defeated by the the Republicans, 33 to 26 . 
Although only two of these major bills were subject to party votes on the floor of the senate, they could have been partisan issues before they got to the floor. Roll call voting is only one part of the legislative process. Many controversial measures are amended in committee to the extent that they cease to be partisan.

The Senate

As stated earlier, the Oregon Senate was controlled by a coalition of Republicans and conservative Democrats during the 56 th session (1971). The senate went through a twelve day deadlock in trying to elect a president. The Democrats had a sixteen to fifteen majority, but senator E. D. Potts, D-Grants Pass, refused to vote with his party, thus causing a fifteen to fifteen tie. On the fifty-fourth ballot, Senator John Burns, D-Portland, defected and gave notice that he would vote for himself for senate president. Burns had previously voted for the regular Democratic nominee, Senator Berkeley Lent, of Portland. Potts and the fourteen Republicans also voted for Burns, thus bringing the Senate under coalition control. 20

This coalition can be seen in the difference between the indices of cohesion of the 56 th session as set forth in Table I. Democratic cohesion was $72 \%$ while Republican cohesion was $80 \%$. The Democrats won only $38 \%$ of the party.

20 Harry Bodine, "Senate Chooses John Burns as President," The Oregonian, 23 Jan. 1971, p. 1, cols. 1-2. 
votes, whereas the Republicans won $62 \%$ of the party votes. T There is an obvious relation between cohesion, size of a party's majority or minority and the number of party votes won. A minority party which is only slightly in the minority and is very cohesive can dominate a majority party which is less cohesive. If a minority party is substantially in the minority, increased cohesiveness will not result in as many victories.

\author{
TABLE I \\ COMPARISON OF PARTY COHESION FOR THE \\ DEMOCRATIC AND REPUBLICAN PARTIES \\ IN THE 56TH SESSION OF \\ THE OREGON SENATE \\ $\because$ Cohesion $\&$ of Roll Call Votes Won \\ (Party Votes)
}

Democrats

Republicans

Number of Party Votes - 93

Actual Number of Bills - 86
72

80
38

62
Number of Democratic Members - 16 Number of Republican Members

(Significant as a sample to the 5\% level) 21

21

$$
t=\overline{\mathrm{x}}_{1}-\overline{\mathrm{x}}_{2} / \sqrt{\mathrm{S}^{2}+\mathrm{s}_{1}^{2}-1 \mathrm{~N}_{2}-2}
$$

by use of a " $t$ " test: $N_{1}$-Subjects in sample \#1 $\mathrm{N}_{2}$-Subjects in sample \#2 $x_{1}$-Mean of sample \#1 $x_{2}$-Mean of sample $\# 2$ $s_{1}^{2}-s t d$. deviation sample \#1 $S_{2}$-std. deviation sample \#2

This test essentially asks, "What is the probability of difference between the means being significant 95 times out of 100 given the size of the sample?" For a specific discussion see: Hubert M. Blalock, Jr., Social Statistics (New York: McGraw-Hill, 1960), p. 226 . 
The term "significance," which is. used both in the text and in the tables, should be explained. Significance refers to the difference between the two means which are being compared. At first glance the eight percent difference in the above table may seem small, but this is deceptive. These means are the actual population behavior, not samples of population behavior, and the difference between them cannot be ignored, regardless of the size. Statistical significance is a moot point in this sense. Significance is reported, however, treating the populations as if they were samples. This is done only as an aid in making any generalizations from the examined populations to larger populations. The lack of cohesion on the part of the Democrats, mentioned above and shown in the Table $I$, is the direct result of the voting patterns of Senators Potts, Burns, and the original founder of the coalition, Harry Boivin, of Klamath Falls. Their individual partisan indices will be given in Table II. If the scores of Potts, Burns and Boivin are excluded, the Democrats would have had an index of cohesion of $80 \%$

One of the most interesting points determined was that relatively few of the bills given consideration underwent party votes. Of the 375 bills voted on by the senate, only 23\% were subject to party votes on either procedural questions or thixd readings. As mentioned earlier, partisan 
conflict is manifested in many areas other than roll call voting; hence; the $23 \%$ figure is perhaps deceptive.

Table II gives the partisan scores of each individual senator. The Democrats had scores ranging from $13 \%$ for senator Potts to $92 \%$. for Senator Burbidge, with a $72 \%$ average. The Republican partisan scores ranged from $55 \%$ for senator Wingard to $91 \%$ for senator Raymond. The median for the Democrats was $76 \%$, while the median for the Republicans was 84\%. The median is that score which falls in the midale if all the scores are arranged in magnitude. Potts, Burns and Boivin, all Democrats, voted with the Republicans more than with their own party. As mentioned earlier, this resulted in the Democrats winning only $38 \%$ of the party votes.

\section{TABIE II}

INDIVIDUAL INDICES OF PARTISANSHIP FOR SENATORS

IN THE 56TH SESSION. PERCENTAGE EACH

IEGISLATOR VOTED WITH EIS OR HER

OWN PARTY ON PARMYY VOTES

\section{Democrats}

$\begin{array}{llll}\text { Bain } & 86 \% & \text { Groener } & 72 \% \\ \text { Boe } & 66 \% & \text { Haas-Lent } 22 & 91 \% \\ \text { Boivin } & 47 \% & \text { Hallock } & 87 \% \\ \text { Browne } & 84 \% & \text { Holstrom } & 69 \% \\ \text { Burbidge } & 92 \% & \text { Mahoney } & 68 \%\end{array}$

22 Senator Berkeley Lent, D-Portland, resigned on May 1, 1971, to accept a judgeship. He was replaced by Representative Harl Haas, D-Portland. Haas resigned his House seat to assume the Senate seat. He was replaced by Representative Keith Burns, D-Portland. Both the scores of Haas and Lent in the Senate and of Haas and Burns in the House are reported for convenience. While they should not be cited as the voting pattern of any one of the individuals, they are two examples of Democratic partisanship. 


$\begin{array}{lrll}\text { Burns H. } & 48 \% & \text { Potts } & 13 \% \\ \text { Cook } & 84 \% & \text { Roberts B. } & 82 \% \\ \text { Fadeley } & 80 \% & \text { Wilner } & 86 \% \\ \text { mean }-72 \% & & \\ \text { median }-76 \% & & \end{array}$

\section{Republicans}

$\begin{array}{llll}\text { Atiyeh } & 87 \% & \text { MacPherson } & 80 \% \\ \text { Carson } & 70 \% & \text { Mackay } & 86 \% \\ \text { Dement } & 84 \% & \text { Newbry } & 83 \% \\ \text { Eivers } & 76 \% & \text { Ouderkirk } & 84 \% \\ \text { Hartung } & 70 \% & \text { Raymond } & 91 \% \\ \text { Hoyt } & 76 \% & \text { Wingard } & 55 \% \\ \text { Jernstedt } 84 \% & \text { Yturri } & 88 \% \\ \text { mean }-80 \% & & \\ \text { median }-84 \% & & \end{array}$

Figure 1 is a graph placing the Democratic senators in rank order relationship. The diagonal line running across the graph divides the legislators into two groups, those who voted with their party more than against their party and vice versa. The individual partisan scores are also given at the bottom of the graph. The graph illustrates the relative extent of cohesion among the senators. As can be seen from the graph, three senators--Burns, Boivin and Potts-are in the lower category, which means they voted against their party more than with their party. This further illustrates the problem of the losing Democratic majority. Figure 2 places the Republicans in the same relationship. Only Senator wingard stands out. Wingard did, however, vote with his party a majority of the time in the 56th session. 
Figure 1. Graph placing Democratic senators in rank-order relationship.

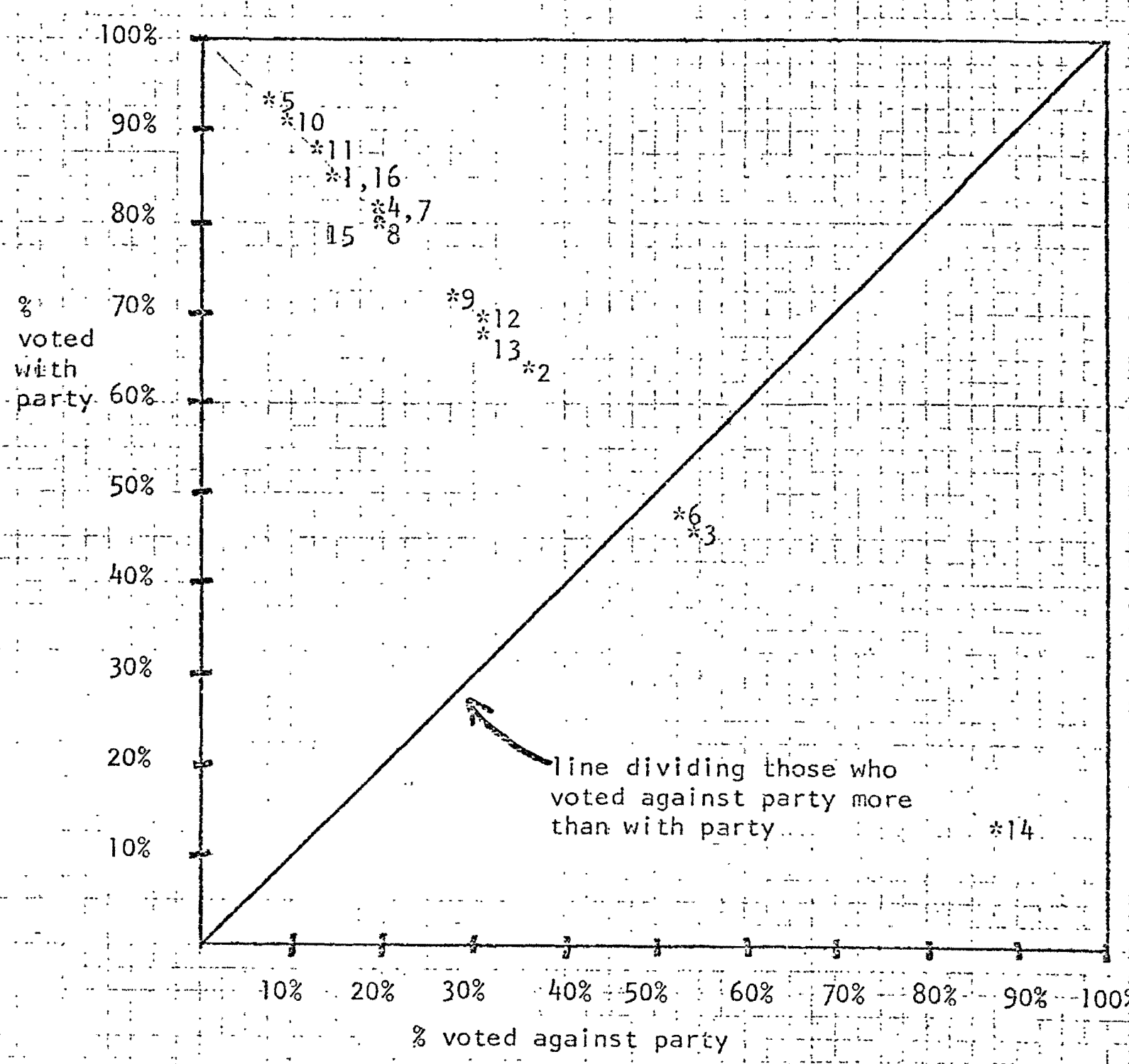

$\begin{array}{llll}\# 1 & \text { Bain } & 86 \% \\ \# 2 & \text { Boe } & 66 \% \\ \# 3 & \text { Boivin } & 47 \% \\ \# 4 & \text { Browne } & 84 \% \\ \# 5 & \text { Burbidge } & 92 \% \\ \# 6 & \text { Burns J. } & 48 \% \\ \# 7 \text { Cook } & 84 \% \\ \# 8 \text { Fadeley } & 80 \%\end{array}$

II Groene $7.2 \%$

\#10 Haas-Lent .. $91 \%$

\#11 Hallock: : $87 \%$

\#12 Holmstrom : 69\%

\#13 Mahoney: : 68\%

\#14 Potts $13 \%$

\#15. Roberts B.. $82 \%$

\#16 Wilner $2.86 \%$

mean $-72 \%$ 
Figure 2: Graph placing Republican senators in rank-order relationship

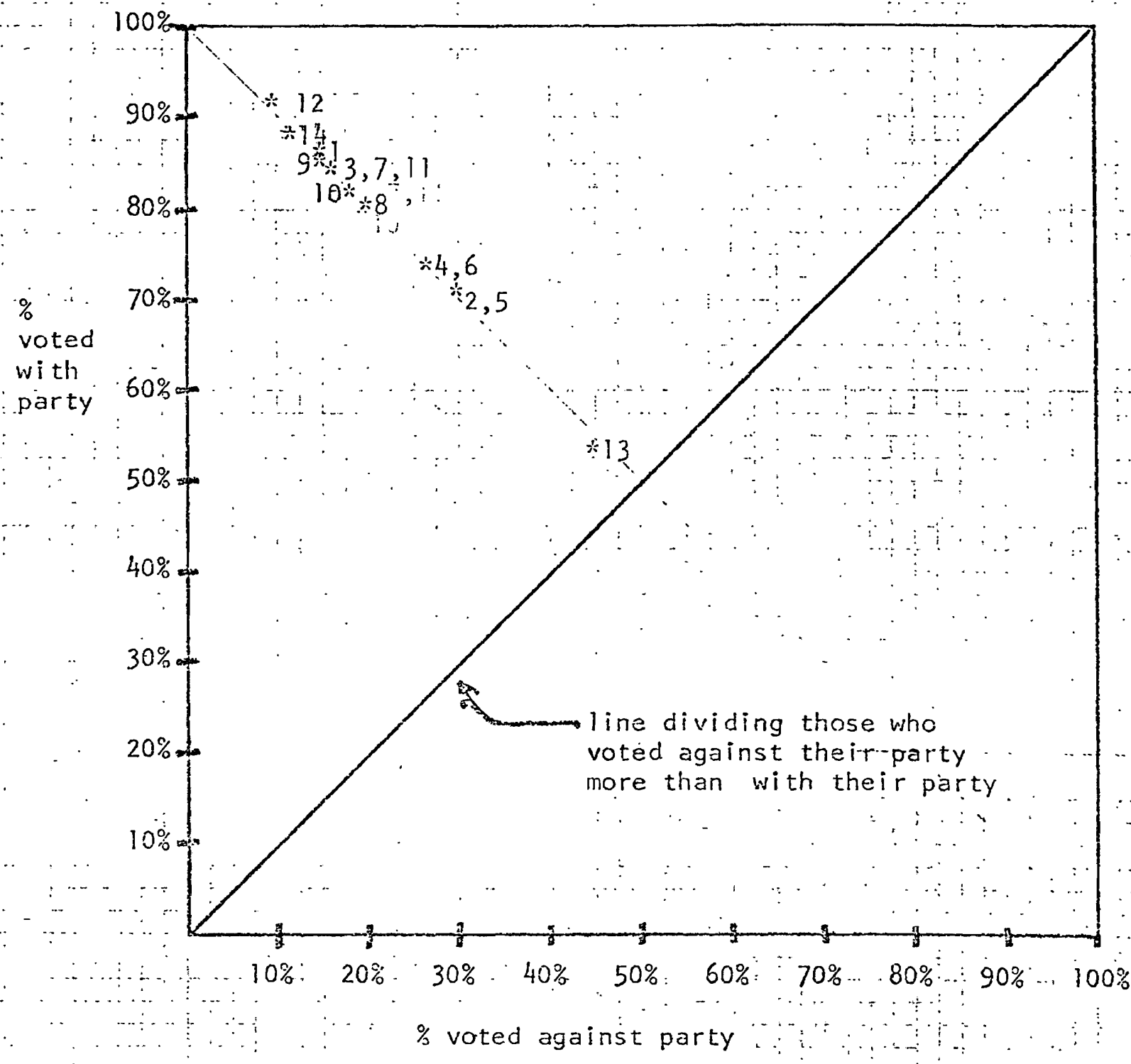

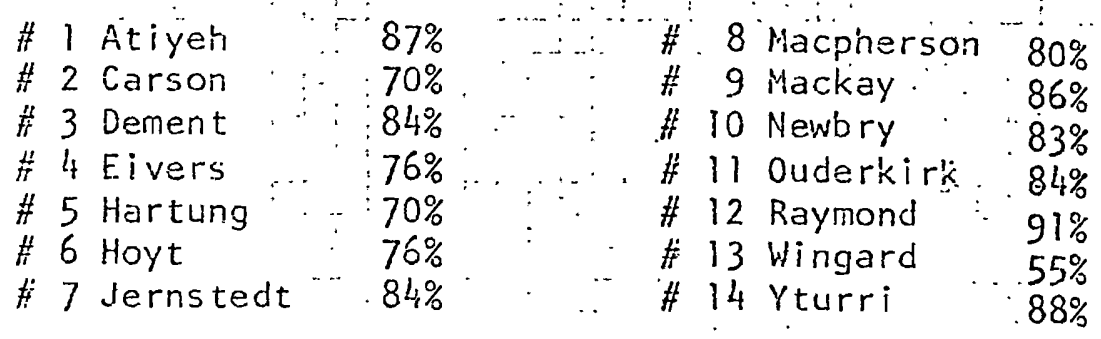

mean $-80 \%$
median $-84 \%$ 
The House

The Republicans controlled the House of Representatives in the 56 th session by a majority of 34 to 26 . The Speaker was Republican Robert Smith of Burns, Oregon. The indices of cohesion are given in Table III. The Democrats had an $84 \%$ index of party cohesion and won $34 \%$ of the party votes. The Republicans had a $77 \%$ index of cohesion and won $66 \%$ of the party votes. Although the Democrats were more cohesive than the Republicans, this could not make up for the eight vote majority held by the Republicans.

\section{TABLE III}

COMPARISON OF COHESION FOR THE DEMOCRATIC AND REPUBLICAN PARTIES IN THE 56TH SESSION OF THE OREGON HOUSE OF REPRESENTATIVES

$$
\text { : Cohesion } \% \text { of Roll Call Votes won }
$$
(Party Votes)

\section{Democrats}

Republicans

Number of Party Votes - 96

Number of Actual Bills - 93
84

77
34

66
Number of Democratic Members -26 Number of Republican Members . $\quad-34$

(Significant as a sample to 5\% level.)

Again, only a relatively small number of bills considered were subject to party votes. In the 56 th session this amounted to only about $10 \%$ of the 622 bills voted on in the House. Of the bills on which party votes occurred, a high proportion (approximately 25\%) had to do with 
elections, reapportionment and other governmental affairs. This is hardly an unusual area for partisan conflict to occur. As noted earlier, the small number of bills is deceptive. The figure should not be considered as a particular index of partisan conflict for the whole legislative process.

On an individual basis the Democrats ranged in partisanship from a low of $51 \%$ for Representative Magruder to 98\% for Representative Frank Roberts. As mentioned earlier, the overall average for Democrats was $84 \%$. The Republicans ranged from $41 \%$ for Representative Elliot to 93\% for Representative Meeker. The Republican average was $77 \%$. The Republicans had a greater range than the Democrats: $52 \%$ versus $47 \%$. The Democratic median was 84.5\% and the Republican median was $78 \%$. None of the Democrats voted with the opposing party more than with their own party in the 56th session. Three Republican Representatives did vote with the Democrats more than with their own party: Representatives Elliot, Graham, and Stathos. 
TABLE IV

INDIVIDUAI INDICES OF PARTISANSHIP FOR REPRESENTATIVES

IN THE 56TH SESSION. PERCENTAGE EACH

LEGISIJATOR VOTED WITH HIS OR HER

PARTY ON PARIY VOTES

\section{Democrats}

$\begin{array}{llllll}\text { Akeson } & 86 \% & \text { Fadeley N. } & 95 \% & \text { Owens } & 91 \% \\ \text { AuCoin } & 81 \% & \text { Haas-Burns } & 95 \% & \text { Peck } & 80 \% \\ \text { Byers } & 82 \% & \text { Heard } & 81 \% & \text { Perry } & 96 \% \\ \text { Cherry } & 86 \% & \text { Hollingsworth } & 73 \% & \text { Ripper } & 83 \% \\ \text { Cole } & 70 \% & \text { Howard } & 77 \% & \text { Roberts F. } & 98 \% \\ \text { Craig } & 95 \% & \text { Kennedy } & 82 \% & \text { Skelton } & 89 \% \\ \text { Densmore } & 90 \% & \text { Lang } & 67 \% & \text { Stevenson } & 84 \% \\ \text { Eymann } & 97 \% & \text { Magruder } & \text { Milits } & 85 \% \\ & & \text { Maher } & 91 \% & \text { Willits } & 67 \%\end{array}$

mean $-84 \%$

median $-84.5 \%$

Republicans

$\begin{array}{llllll}\text { Anunsen } & 78 \% & \text { Ingalls } & 67 \% & \text { Patterson } & 92 \% \\ \text { Bazett } & 92 \% & \text { Johnson L. } & 89 \% & \text { Paulus } & 71 \% \\ \text { Chuinard } & 84 \% & \text { Johnson S. } & 83 \% & \text { Pynn } & 88 \% \\ \text { Collett } & 76 \% & \text { Kinsey } & 64 \% & \text { Rieke } & 61 \% \\ \text { Crothers } & 76 \% & \text { MacPherson } & 78 \% & \text { Smith } & 90 \% \\ \text { Elliot } & 41 \% & \text { Mann } & 74 \% & \text { Stathos } & 40 \% \\ \text { Graham } & 42 \% & \text { Markham } & 90 \% & \text { Stults R. } & 84 \% \\ \text { Gwinn } & 67 \% & \text { Martin } & 83 \% & \text { Thornton } & 78 \% \\ \text { Hanneman } & 78 \% & \text { McGilvra } & 75 \% & \text { Walden } & 92 \% \\ \text { Hansell } & 85 \% & \text { Mckensie } & 75 \% & \text { Young } & 92 \% \\ \text { Henderson } & 78 \% & \text { Meeker } & 93 \% & & \\ \text { Howe } & 86 \% & \text { Nyberg } & 85 \% & & \end{array}$

mean -77

median -78

Figure 3 places the Democratic representatives in rank order relationship. All the Democrats voted with their party more than with the Republican party. Figure 4 shows the rank ordering of the Republicans. Three Republicans stand out, Graham at 42\%, Elliot at $41 \%$ and stathos at $4.0 \%$ 
Figure 3.. Graph placing Democratic representatives in "rank-order relationship.

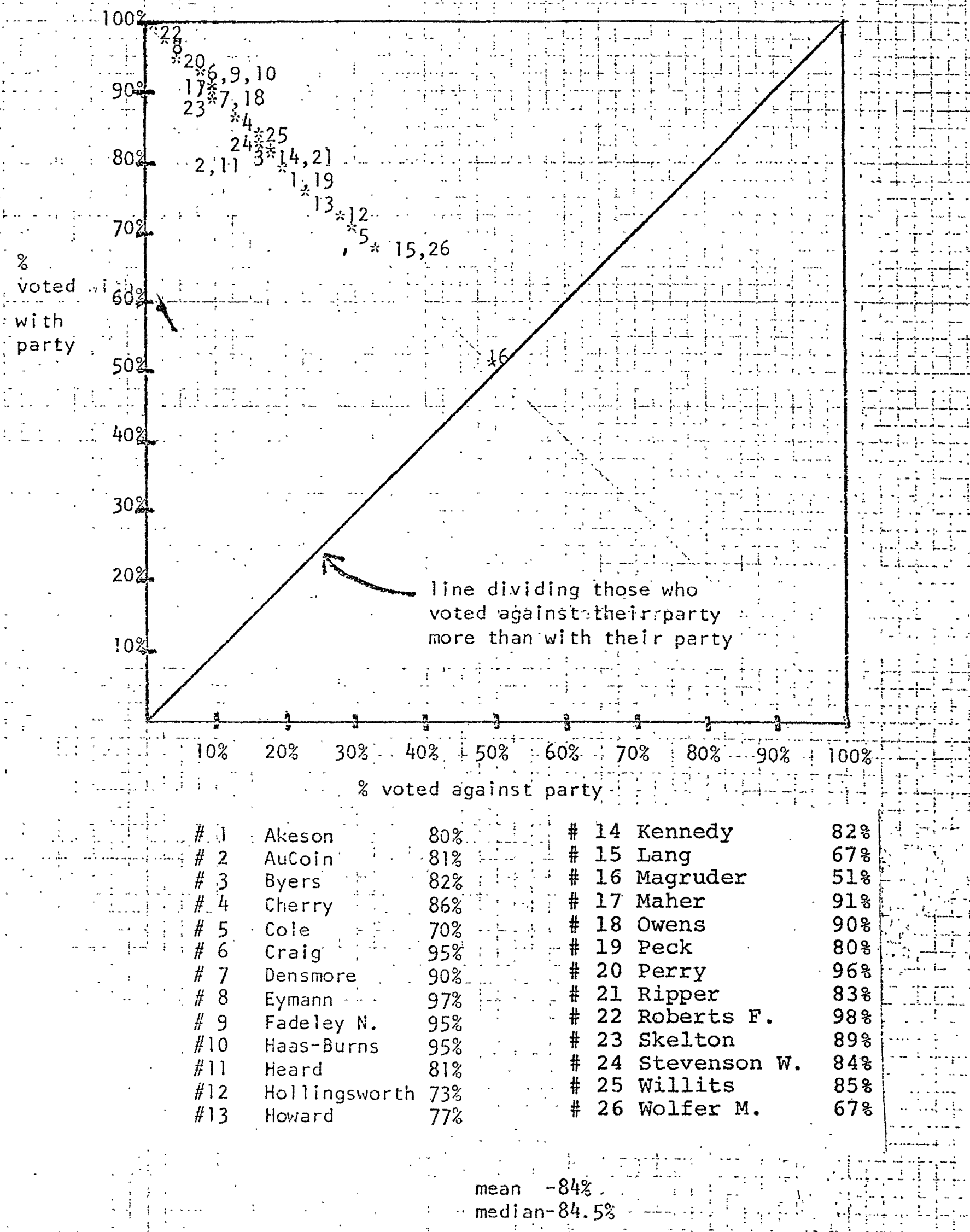


Figure 4.Graph placing Republican representatives in rank-order relationship:

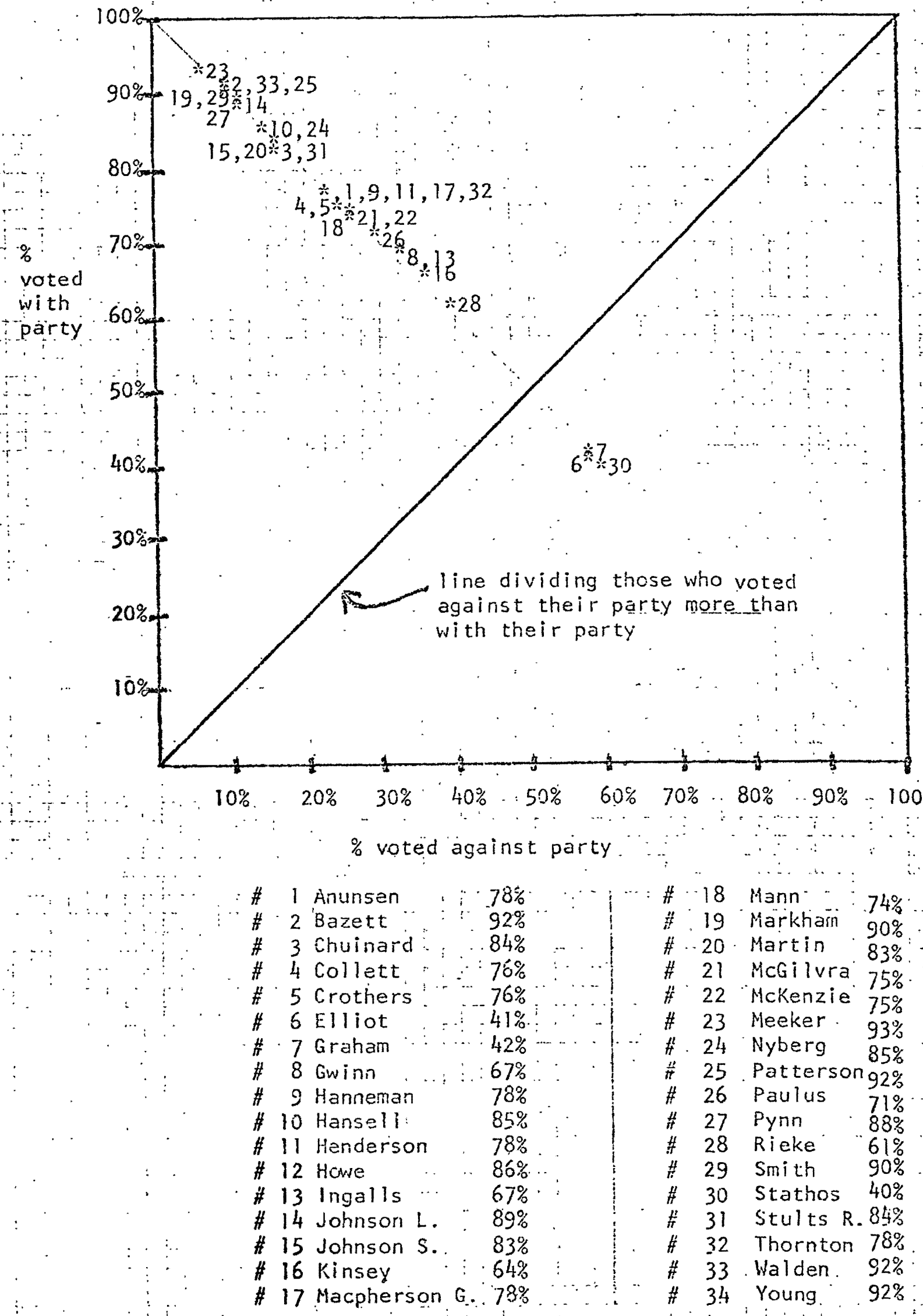


CHAPTER IV

THE 57TH SESSION

General Description of the Session

The 57th Session of the Oregon Legislature, in 1973, was. the longest in the state's history, lasting one hundred and eighty days. More bills were introduced than ever before, a total of two thousand, five hundred. Among significant pieces of legislation passed by both of the Democratically controlled houses were:

SB 100 - This was the land use planning bill, which established a statewide Land Conservation and Development Commission. Its purpose was to control urban sprawl and excessive development of Oregon's scenic areas.

- SB 187 - This bill increased workman's compensation to $-80 \%$ of the individual's normal weekly salary. This was a major victory for labor.

HB 2004 - This was the ill-fated tax plan of Governor McCali's. The measure increased personal and corporate income taxes and had the state paying $90 \%$ of the basic. school support. It also removed the property tax on homes. The measure was defeated in a May 1st referendum. AIthough the legislature passed a second series of measures for school support and property tax relief, these were not nearly as extensive as the original plan.

HB 3077 - This was a Iimit on campaign spending. Those running for statewide office would be limited to 
fifteen cents per registered voter per election. Those running for legislative office would be limited to twentyfive cents per registered voter per election.

SB 100 was subject to one party vote in the House. It was a procedural motion to refer the bill back to committee. The Republicans lost, 25 to 34 .

HB. 2004 was subject to party votes in both the House and the Senate. In the House there was one party vote. The minority report was rejected, with the Democrats winning 23 to 36 . In the senate the bill was subjected to six party votes. The Republicans won a procedural vote to reject the committee report, 13 to 17 . They. lost the four other procedural votes and the final third reading.

In addition to the length and volume of legislation considered, the session was notable for the vast amount of public participation in both regular hearings and lobbying activities.

\section{The Senate}

The Senate came under regular Democratic control for $\sqrt{ }$ the first time in this century during the 57 th session. The Democrats held an 18 to 12 majority, and all Democratic members voted for the Democratic nominee for Senate president, Senator Jason Boe, D-Reedsport.

Indices of cohesion are found in Table $V$. Democratic cohesion increased slightly from the $72 \%$ of the 56 th session to $76 \%$ for the 57 th session. The Democrats also won 
$70 \%$ of the party roll call votes. Republican cohesion decreased from $80 \%$ for the 56 th session to $76 \%$ for the 57 th session. The Republicans won only $30 \%$ of the party roll call votes. Increased Democratic cohesion, combined. with a decrease in Republican cohesion and an increased Democratic majority (18 instead of 16 , as in the 56 th session) enabled the Democrats to win $70 \%$ of the party votes. After being in a numerical majority for several years, the regular Democrats had gained control.

\author{
TABLE V \\ COMPARISON OF PARTY COHESION FOR THE \\ DEMOCRATIC AND REPUBLICAN PARTIES \\ FOR THE 57TH SESSION OF THE \\ OREGON SENATE \\ 응 Cohesion \\ ㅇ of Roll Call Votes Won \\ (Party Votes)
}

Democrats

Republicans

Number of Party Votes - 117

Number of Actual Bills - 78
74

76
70

30

$$
\begin{aligned}
& \text { Number of Democratic } \\
& \text { Senators } \\
& \begin{array}{c}
\text { Number of Republican } \\
\text { Senators }
\end{array}
\end{aligned}
$$

(Difference in means not significant as a sample.)

Individual indices of partisanship for the Democrats ranged from 39\% for senator Thorne to $91 \%$ for Senator william Stevenson. The average index of partisanship for the Democrats was $74 \%$. The Republicans ranged from $47 \%$ for Senator Wingard to $86 \%$ for Senator Atiyeh, with an average of $76 \%$. Wingard also had the lowest Republican 
partisan score in the 56 th session. Wingard is elected from a heavily Democratic district in Eugene. The median for the Democrats was $79 \%$, while the median for the Republicans was 748 .

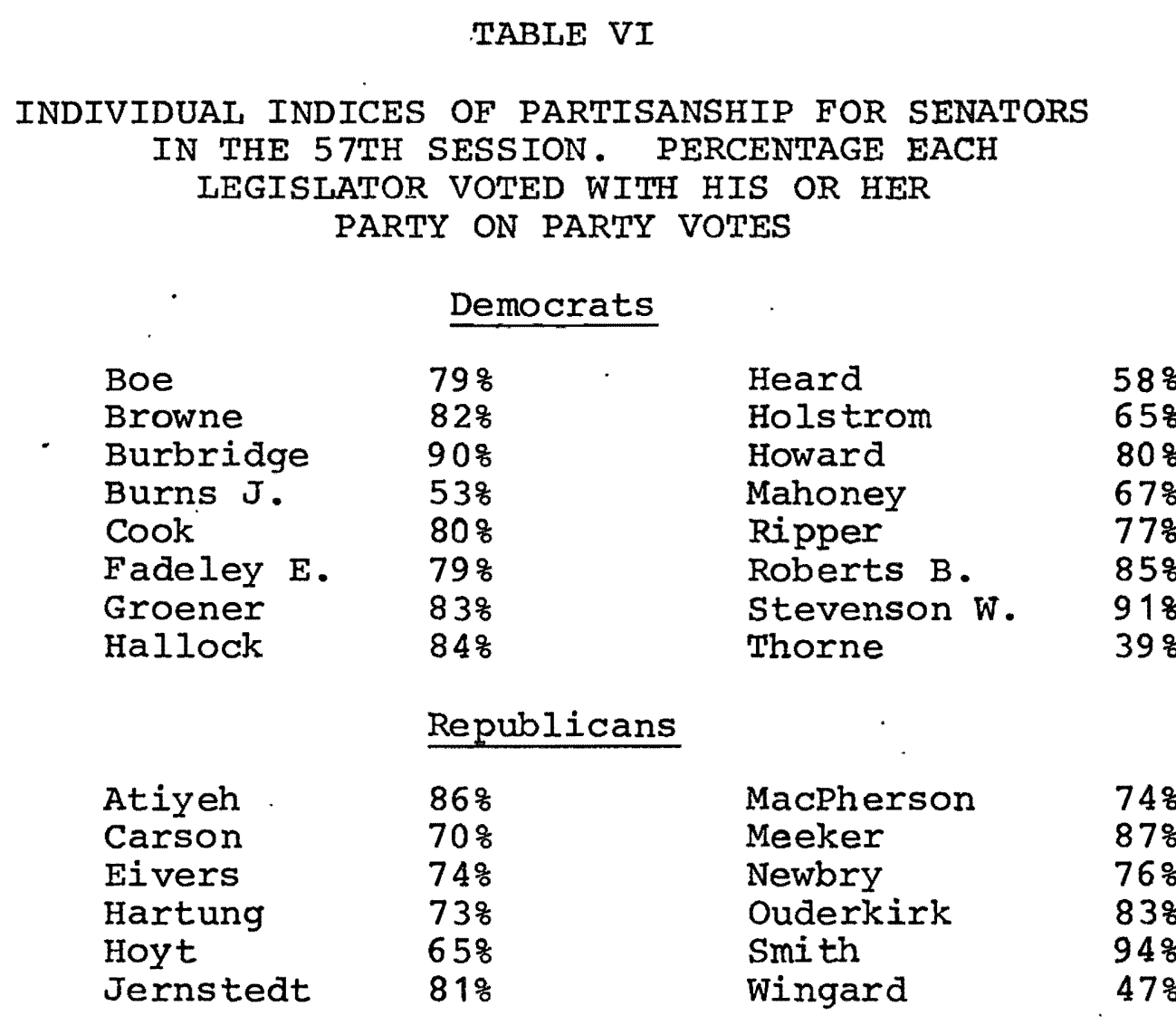

A particularly interesting aspect is the change in the partisanship of Senator Potts. Potts went from a partisan score of $13 \%$ in the 56 th Session to a $52 \%$ partisan score in the 57 th Session. Whether this was due to change of heart or political expediency is up to conjecture. Senator John Burns, the previous coalition Senate president, improved only slightly, from $48 \%$ in the 56 th 
Session to $53 \%$ in the 57th Session. Both Potts and Burns were the Democratic members of the coalition in the $56 \mathrm{th}$ Session.

The Democrats also had trouble holding two of their new senators. Fred Heard, from Klamath Falls, had a partisan score of $58 \%$. Heard assumed the senate seat previously held by the coalition founder, Harry Boivin. Mike Thorne from Eastern Oregon had a partisan score of only 398 .

Figure 5 places the Democratic senators in rank order relationship. Again the most evident deviation is on the part of Senator Thorne. Figure 6 places the Republicans in rank order relationship. Senator Wingard again stands out at $47 \%$.

\section{The House}

The House came under Democratic control for the first time in ten years. With a six vote majority, Representative Richard Eymann, D-Springfield, was elected Speaker. The Democrats' cohesiveness dropped from $84 \%$ in the 56 th Session to $72 \%$ in the 57th Session. Republican cohesiveness dropped from $77 \%$ in the 56 th session to $75 \%$ in the 57th Session. The Democrats won $57 \%$ of the party votes and the Republicans won $43 \%$ of the party votes. Their indices are set forth in Table VII. 


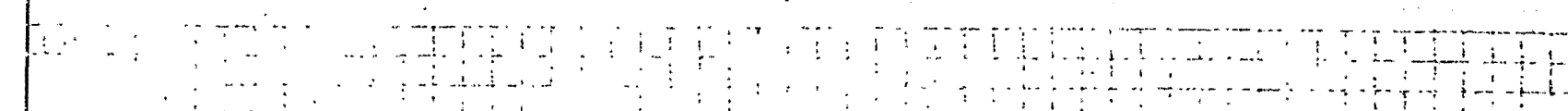

Figure 5. Graph placing Democratic senators in rank-order relationship.

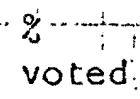

with

party

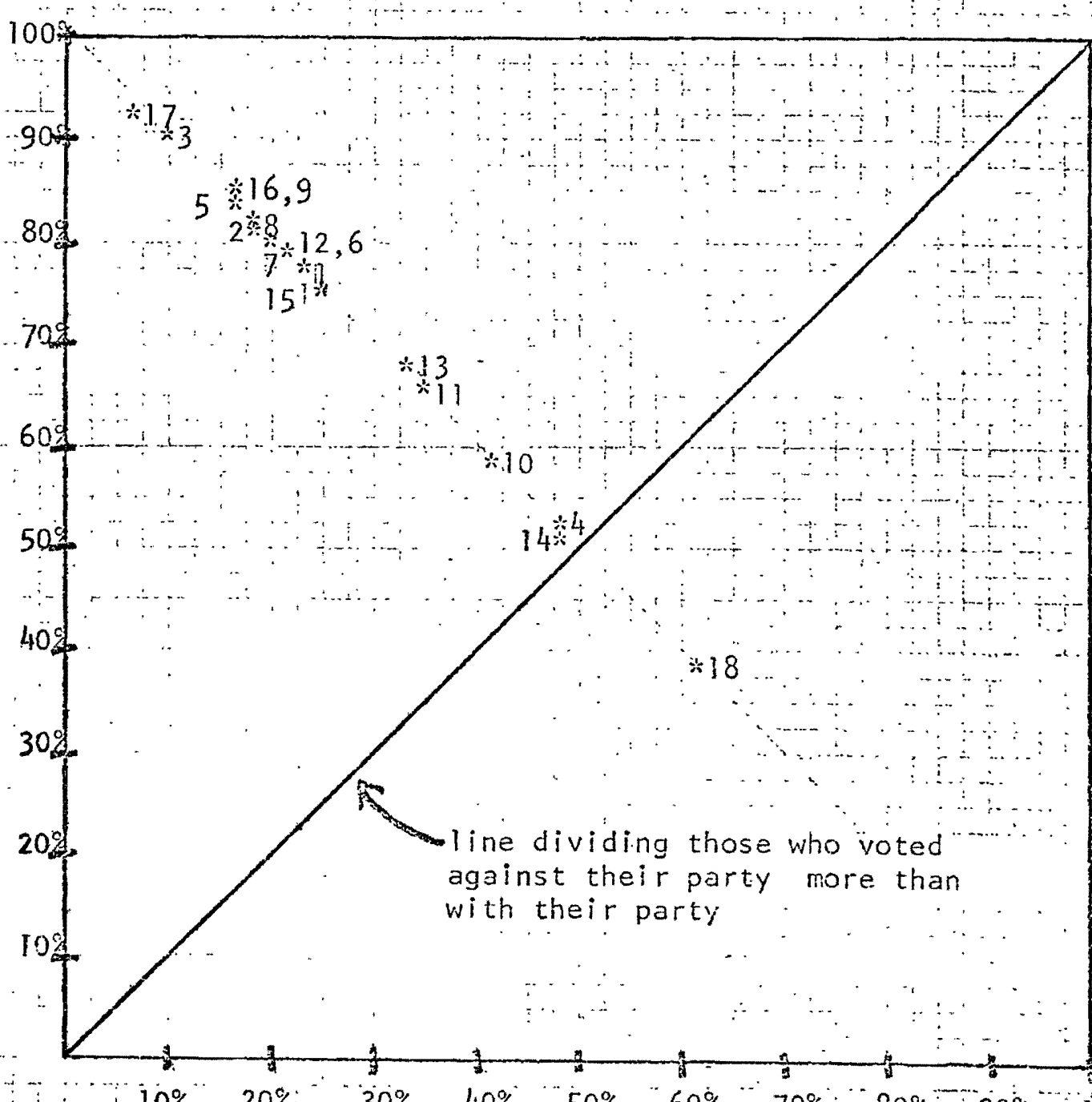

$10 \%: 20 \%: 30 \% \quad 40 \%, \ldots 50 \%, 60 \%, 70 \%, 20 \%, 90 \%, 100 \%$

$\%$ voted against party

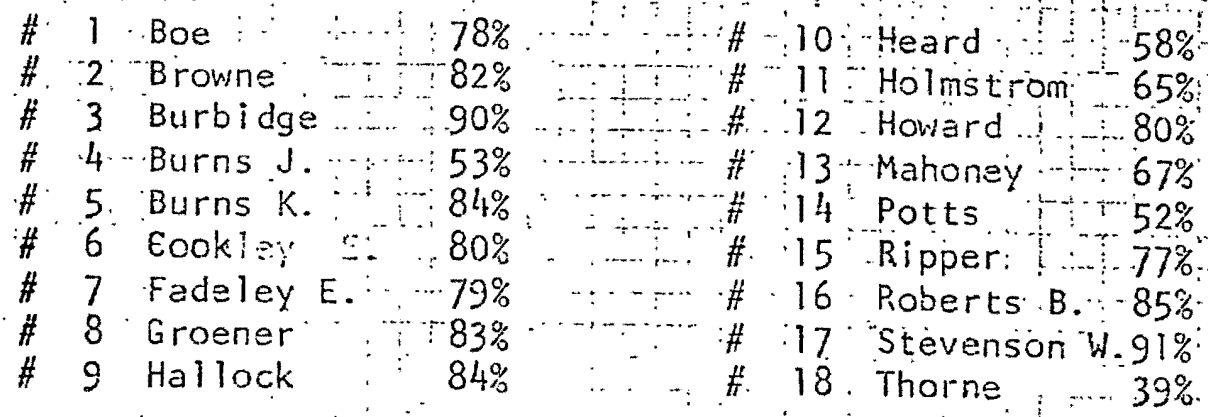

mean $-74 \%$

median-79\% 
Figure 6: Graph placing Republican senators in rank-order relationship.

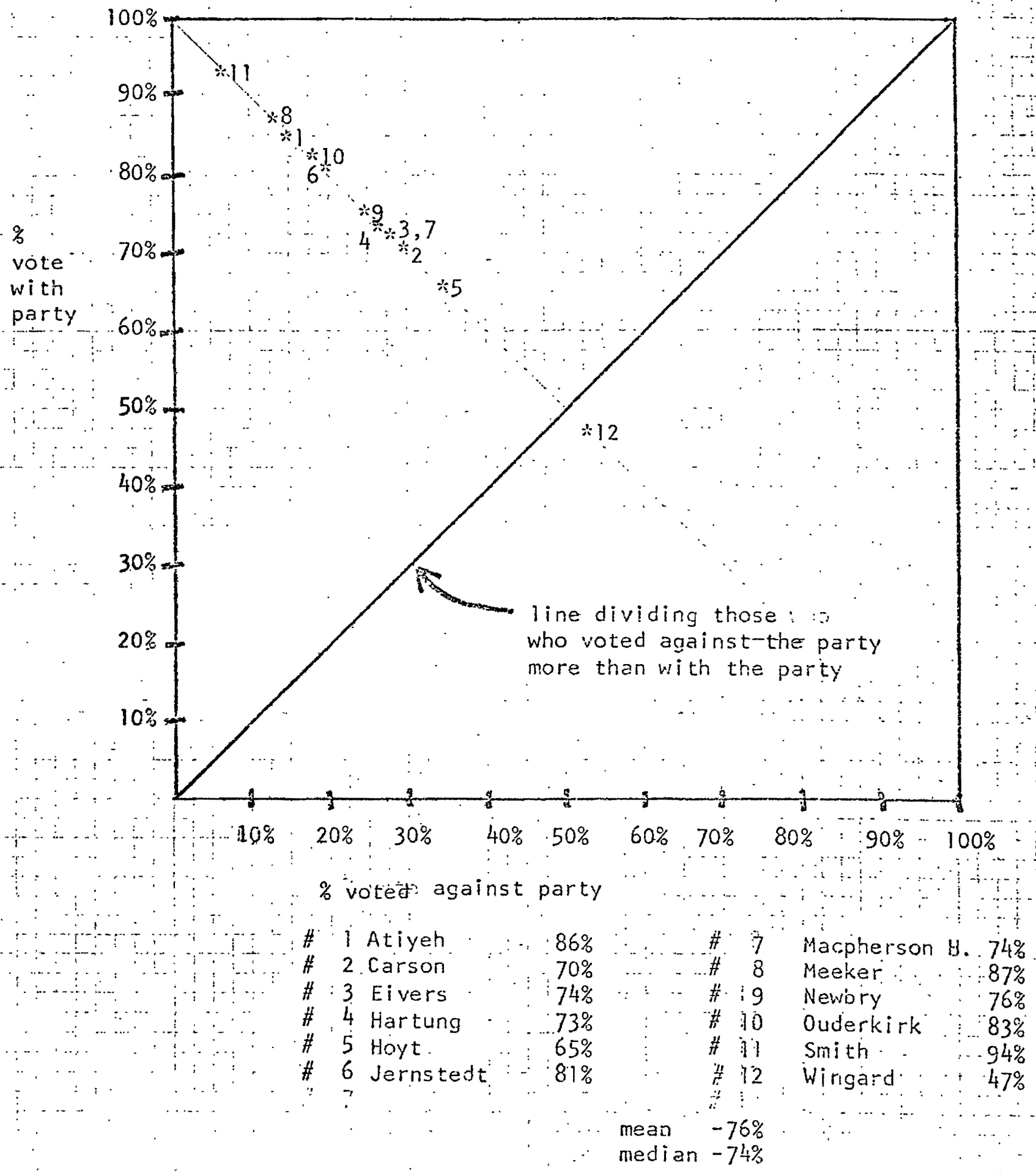


TABLE VII

COMPARISON OF PARTY COHESION FOR THE DEMOCRATIC AND REPUBLICAN PARTIES IN THE 57TH SESSION.

OF THE OREGON HOUSE OF REPRESENTATIVES

\% Cohesion $\%$ of Rol1 Call Votes won (Party Votes)

Democrats

Republicans

Number of Party Votes -182

Number of Actual Bills - 78
57

43

Number of Democratic Representatives - 33 Number of Republican Representatives $\quad-27$

(Difference of means not significant as a sample.)

Although there were a greater number of party votes for the House in the 57th Session, the actual percentage of the total bills considered remained small. Of the $994 \mathrm{bills}$ considered by the House, partiy votes occurred on only about eight percent.

While the Democrats controlled the House, they did not dominate the party voting as did the Democrats in the senate. Whereas in the senate the Democrats won $70 \%$ of the party votes, in the House they won only 57\%. Although the Senate Democrats had a greater proportional majority, the House Democrats should probably have won more of the party votes. In the 56 th Session the Republicans won 668 of the roll call votes with an eight member majority, even though the Democrats were $7 \%$ more cohesive. In the 
57 th Session the Democrats had a six vote majority and were only 3\% less cohesive than the Republicans; yet they won only $57 \%$ of the party votes.

The $12 \%$ drop in Democratic cohesiveness between the 56 th and 57 th Sessions ( $84 \%$ to $72 \%$ ) was due mainly to the decreased partisanship on the part of several returning Democrats and the lower partisanship on the part of several newly elected Democrats. Individual partisan scores for the Democrats ranged from $12 \%$ for Representative Magruder to $95 \%$ for Representative Nancie Fadeley. The average, as previously mentioned, was $72 \%$. The median score for the Democrats was $80.5 \%$. In addition to Magruder, the Democratic majority had trouble with several of its other members: These included Representatives Gilmour, with a score of $19 \%$; Sumner, with a score of $48 \%$; Curt wolfer, with a score of $35 \%$; and Martin Wolfer, with a score of 45\%. All of these individuals voted with the Republicans more than half the time on party votes. These five votes reduced the Democratic majority to a minority on several occasions. All five were from rural areas:

Individual Republican indices of partisanship ranged from $37 \%$ for Representative Rieke to $90 \%$ for Representative Patterson, with an average of $75 \%$. In addition to Rieke, Representative Kinsey, with a partisan score of $49 \%$, also voted with the Democrats more than half the time. Although both parties had defections, the Democratic defections 
were greater and more numerous. Common characteristics of representatives and senators with low partisan scores will be discussed later. The median score for Republicans was 84\%. Individual indices for both Democrats and Republicans are found in Table VIII.

\section{TABLE VIII}

INDIVIDUAL INDICES OF PARTISANSHIP FOR REPRESENTATIVES

IN THE 57TH SESSION. PERCENTAGE EACH LEGISLATOR VOTED WITH HIS OR HER

PARTY ON PARTY VOTES

Democrats

$\begin{array}{llll}\text { Akeson } & 75 \% & \text { Magruder } & 12 \% \\ \text { AuCoin } & 91 \% & \text { Marx } & 80 \% \\ \text { Blumenauer } & 81 \% & \text { McCoy } & 93 \% \\ \text { Byers } & 55 \% & \text { Otto } & 63 \% \\ \text { Cherry } & 69 \% & \text { Peck } & 67 \% \\ \text { Cole } & 62 \% & \text { Perry } & 81 \% \\ \text { Densmore } & 87 \% & \text { Priestley } & 78 \% \\ \text { Derell } & 81 \% & \text { Roberts M. } & 86 \% \\ \text { Eymann } & 87 \% & \text { Skelton } & 67 \% \\ \text { Fadeley N. } & 95 \% & \text { Stevenson } & 76 \% \\ \text { Gilmour } & 19 \% & \text { Sumner } & 48 \% \\ \text { Granell } & 85 \% & \text { Whallon } & 65 \% \\ \text { Groener } & 83 \% & \text { Whiting } & 93 \% \\ \text { Kafoury } & 88 \% & \text { Willits } & 88 \% \\ \text { Katz } & 85 \% & \text { Wolfer C. } & 35 \% \\ \text { Lang } & 78 \% & \text { Wolfer M. } & 45 \% \\ \text { Lindquist } & 88 \% & & \\ \text { mean }-72 \% & & & \\ \text { median - } 80.5 \% & & & \end{array}$

Republicans

Bazett

Bunn

Burrows

Elliot

Gwinn

Hampton

Hanneman

Hansell
$89 \%$

$79 \%$

$54 \%$

$50 \%$

$53 \%$

$77 \%$

$84 \%$

$74 \%$
Markhan

Martin

Morris

Oakes

Patterson

Paulus

Ragsdale

Rieke
$89 \%$

$79 \%$

$86 \%$

$84 \%$

$90 \%$

$56 \%$

$79 \%$

$38 \%$ 
Ingalis

Johnson $L$.

Johnson $S$.

Jones

Kinsey

MacPherson G.

mean $-75 \%$

median $-84 \%$
Stults $D$.

Stults R.

Walden

Whitehead

Wilhelms
$86 \%$

$88 \%$

$88 \%$

$66 \%$

$85 \%$

Figure 7 gives the Democratic representatives in rank order relationship. As can be seen from the graph, there were four Democrats. Who voted with the Republicans more than with their own party. This has been previously. mentioned.

Figure 8 places the Republican representatives in rank order relationship. Kinsey at $49 \%$ and Rieke at $38 \%$ stand out in relation to the other Republicans.

At one time during the session there were rumors of a possible coalition being formed between the Republicans and six of the Democrats. These latter included Gilmour, Magruder, Sumner, C. Wolfex and M. Wolfer, who were mentioned previously in reference to their low partisan scores. The sixth Democrat was Representative Harvey Akeson. AII of the six had opposed the original McCall tax plan and had drafted a letter to speaker Eymann asking for a voice in the writing of the new tax plan. Eymann appointed Martin Wolfer to the special committee which eventually did write an alternative tax plan. No sooner had the six started to congratulate themselves on their success than Eymann struck back and removed Magruder and Gilmour from 
Figure 7. Graph placing Democratic representatives in rank-order relationship.
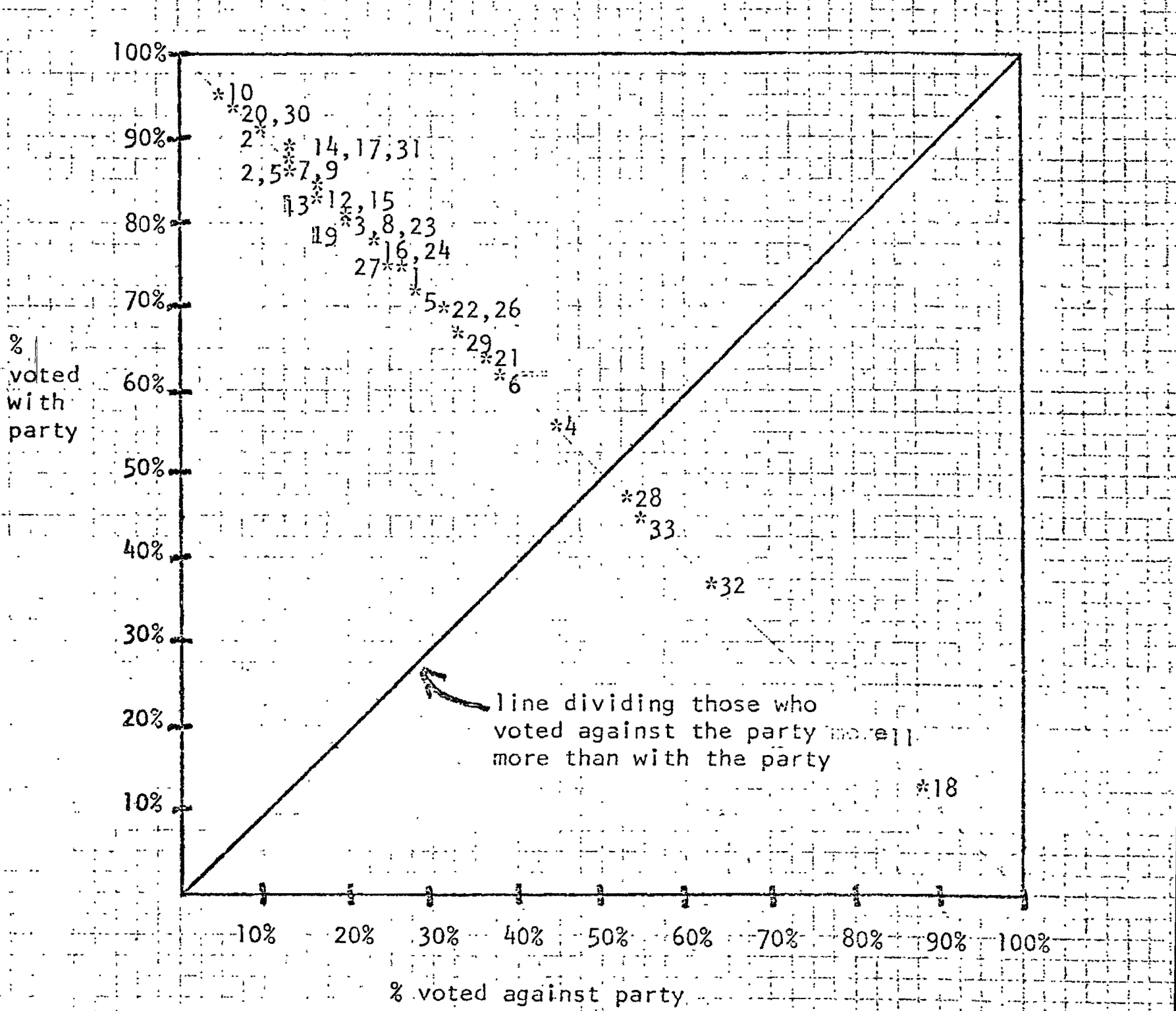

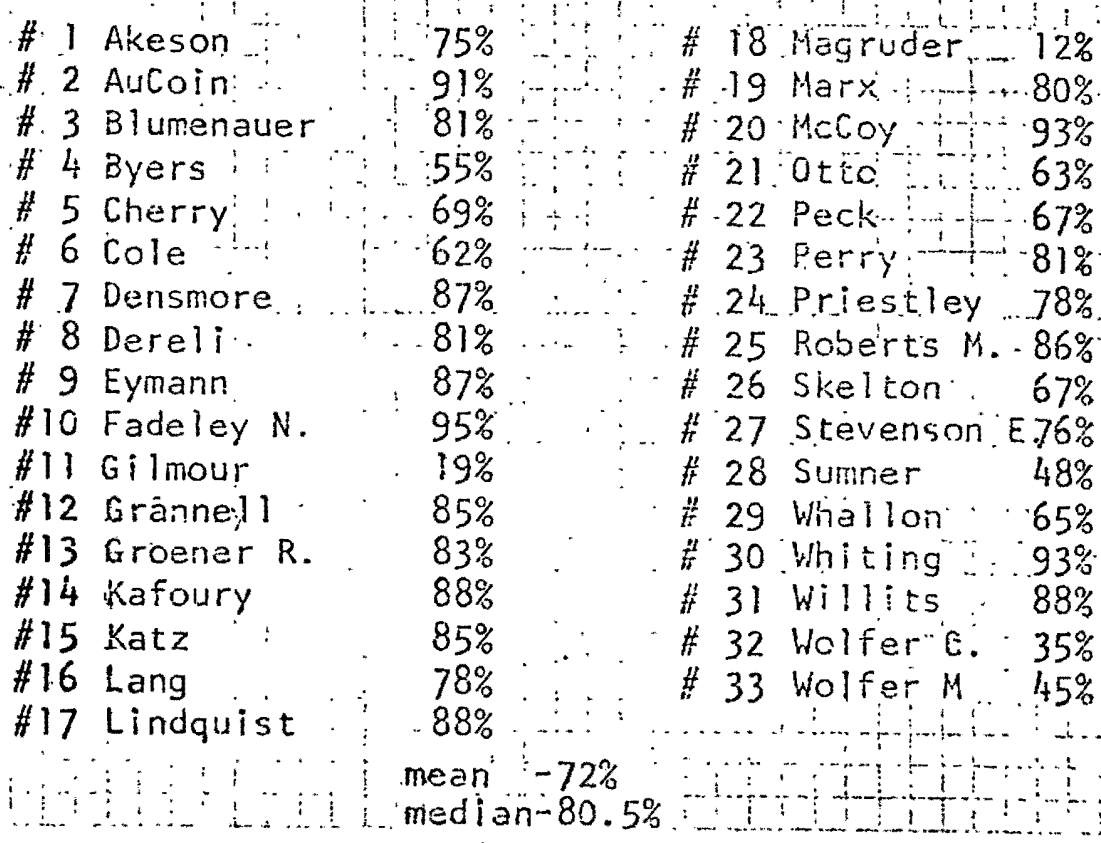


Figure 8. Graph placing Republican representatives in rank-order relationship.

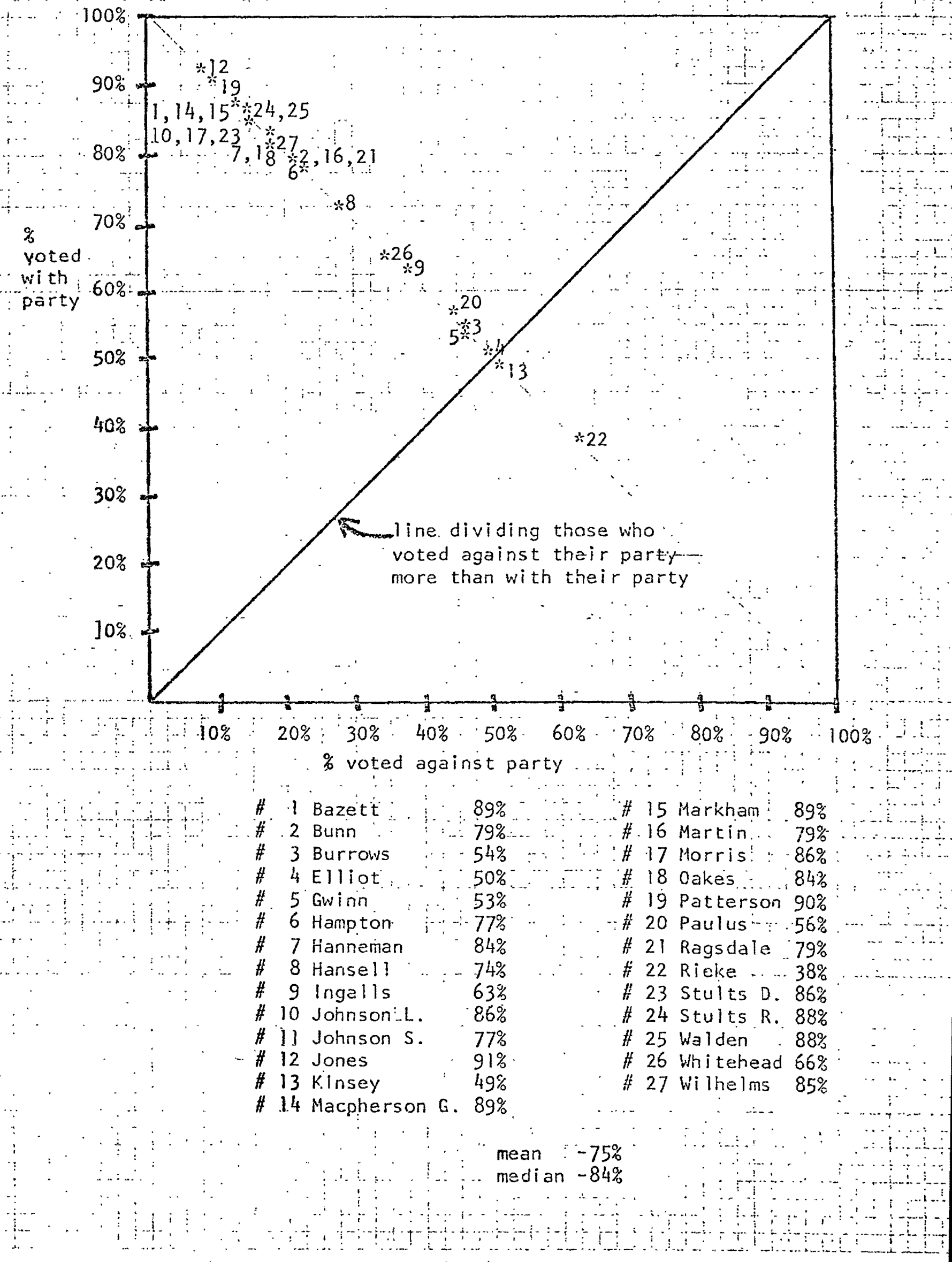


theix positions as chairman and vice-chairman of the Consumer and Business Affairs Committee. Eymann said specifically that he wanted to discourage any possibility of coalition politics in the House. The main barrier to a coalition being formed, according to several sources, was the possibility that several of the urban Republicans would not join in the attempt. ${ }^{23}$ Both Representatives Magruder and Gilmour had been consistently voting with the Republicans on procedural questions. As mentioned earlier, procedural questions are supposedly the only votes which require voting with the party leadership. This is an informal caucus agreement.

Coalition politics is a fascinating subject. It has been a constant element in oregon since 1961 and the original senate coalition. Motivations for forming coalitions go beyond conservative/liberal attitudes into the realm of regional feeling and personal ambition. The original 1961 coalition was based to a great extent on fears the down-state legislators had of being dominated by urban and up-state legislators. Ambition was probably the most likely reason for the 1971 coalition which elected senator Burns as Senate President. Regardless, full consideration of the subject deserves a separate and extensive work.

23 This type of observation is impossible to document because it was obtained through off-the-record interviews. It is relevant to the actual event and, in the author's judgment, reliable. 
AREAS OF INOUIRY

There were six areas of inquiry relating to partisan voting in the oregon Legislature. These were: the two major parties themselves, urban legislators, women legislators, legislators under 30 , freshmen legislators and legislators representing single member districts.

Each of these areas or topics has a certain amount of the previously mentioned folk wisdom about it. For instance, Republicans are usually thought to be more partisan than Democrats; there is, supposedly, less dissension in the Republican party. Do the results of this study confirm or deny such political folk wisdom?

The Two Major Parties

As stated above, Republicans are supposed to be more partisan than Democrats. This was the case in three out of four instances which were examined. In only one instance were the Democrats more cohesive than the Republicans; this was in the 56 th Session of the House when the Democrats had a partisan score of $77 \%$. For the senate in the 56 th Session, the Republicans were more cohesive, $80 \%$ to $72 \%$. The RepubIicans were more cohesive in the House in the 57th session, 75\% to 72\%. The Republicans were more cohesive in the Senate, $76 \%$ to $74 \%$. Some of the differences in percentages 
are slight. These are not samples, however, but measurements of actual population behavior, and therefore, a valid description of the actual events.

\section{TABLE IX}

COMPARISON OF COHESION OF THE TWO PARTIES OVER THE TWO SESSIONS IN BOTH HOUSES

$\begin{array}{ccrr}\text { Senate } & \text { Senate } & \text { House } & \text { House } \\ 56 \text { th } & 57 \text { th } & 56 \text { th } & 57 \text { th }\end{array}$

Democrats

$72 \%$

- $74 \%$

$84 \%$

72 웅

Republicans

$\frac{80 \% *}{\text { Dem Maj }}$

$\frac{76 \%}{\text { Dem Maj }}$

$\frac{77 \% *}{\operatorname{Rep} M a j}$

$\frac{75 \%}{\text { Dem Maj }}$

(*Difference of means significant to 5\% level.)

One fact did emerge, however; the minority party was more cohesive than the majority party in all four cases. (If the fourteen regular Senate Democrats are considered the "minority" in the 56 th Session, they, too, were more cohesive than the "majority" coalition, $82 \%$ to $79 \%$ ) Whether this is due to size or other factors is hard to determine. $\checkmark$ It is very possible that the minority party perceives itself as a minority party and feels a special necessity to vote as a whole. Several legislatoxs were interviewed in reference to this point. They agreed with the basic premise and pointed out that many of the freshmen Democratic legislators who had low partisan scores had never been part of a minority and did not know what it was like. This would be an appropriate topic for further research. 
Urban Legislators

Comparing urban legislators to nonurban legislators is highly appropriate for the oregon Legislature. Sectional interests play a very important role in some decisions. For example, support for mass transit is rather difficult to find among down-state legislators:

Oregon has in its demographic spectrum areas which are densely urban as well as those which are extremely rural. Urban legislators were among the groups examined in the previously mentioned studies. A comparison of results is appropriate.

An urban legislator is defined as one who represents a portion of any city with a population of 80,000 or more. This effectively confines consideration to the Portland and Eugene areas. It is more useful to have an objective, exclusive definition of what is urban than a more subjective, inclusive definition. An exclusive definition of urban will give "pure" or unadulterated population to measure. If an inclusive definition is used, the partisanship of more than urban legislators would be measured. The interest is in urban legislators per se and not in legislators from partially urban areas, rural areas, or suburban areas. At the same time, an objective standard is needed. The peculiarities of legislative boundaries and the fact that all districts have approximately the same population makes any other definition unworkable. Even using the 
80,000 population figure, one representative and one senator who represented both urban and rural areas were included. Representative Glenn otto and Senator Vern Cook have large rural areas in their districts, as well as part of Portland. Other possible definitions would have only compounded this problem. Grum had a similar problem in $h$ is work with the Kansas Legislature. He notes that the use of the usual census definition of urban is inappropriate. 24 Grumm eventualiy used his own definition of urban for his study of the Kansas Legislature. He placed the urban areas in rank order and ran correlations between those areas and the voting patterns of the various legislators in reference to certain types of legislation. As set forth in Table $x$, urban senate Democrats had an average partisan score of $78 \%$, as opposed to $74 \%$ for all senate Democrats. The one senate Republican who could be classified as urban, Senator Wingard, had a partisan score of only $47 \%$, as opposed to $75 \%$ for the senate Republicans as a whole. Senator Wingard voted with the Demo-. crats on party votes more than he voted with his own Republican party. As mentioned before, Wingard was elected from a heavily Democratic district in Eugene. About $18 \%$ of the party votes on which wingard dissented involved labor issues. This was one of the few instances in which a particular type of issue stood out.

24 Grumm, p. 348. 
In the House, the urban Democrats had an average partisan score of $79 \%$, as opposed to $72 \%$ for all the Democrats. Urban Republican representatives were significantly less partisan than Republicans as a whole. The average . partisan score of urban Republicans was $51 \%$ as compared to 75\% for Republicans as a whole. The urban Republicans voted with the Democrats almost half the time on party votes.

All of these findings seem to confirm the popular folk wisdom that urban legislators are more "liberal" than legislators as a whole. Of course, one has to make the association between liberal and Democratic. "This is not an untenable proposition and is necessary if some of the popular conceptions about oregon politics are to be tested. Grumm found a very high correlation between liberal and Democratic in his study. 25

25 Grumm, p. 351 
TABLE X

INDICES OF PARTISANSHIP FOR URBAN LEGISIATORS IN THE 57TH SESSION

\section{SENATE}

wingard

Meàn

Mean for all R's

Median

\section{$\underline{\text { Republicans }}$}

$47 \%$

$47 \%$

$76 \%$

$47 \%$
Democrats

$\begin{array}{ll}\text { Burns J. } & 53 \% \\ \text { Burns K. } & 84 \% \\ \text { Cook } & 80 \% \\ \text { Fadeley E. } & 79 \% \\ \text { Hallock } & 80 \% \\ \text { Howard } & 80 \% \\ \text { Mahoney } & 67 \% \\ \text { Roberts B. } & 85 \% \\ \text { Stevenson W. } & 91 \% \\ \text { Mean } & 78 \% \\ \text { Mean for all D's } 74 \% \\ \text { Median }\end{array}$

\section{HOUSE}

R̈epubIicans

$\begin{array}{ll}\text { Burrows } & 54 \% \\ \text { Elliot } & 50 \% \\ \text { Kinsey } & 49 \% \\ \text { Rieke } & 38 \% \\ \text { Whitehead } & 66 \% \\ \text { Mean } & 51 \% \\ \text { Mean for all R's } & 75 \% \\ \text { Median } & 50 \%\end{array}$

Democrats

$\begin{array}{ll}\text { Akeson } & 75 \% \\ \text { Blumenauer } & 81 \% \\ \text { Cherry } & 69 \% \\ \text { Kafoury } & 88 \% \\ \text { Katz } & 85 \% \\ \text { Lang } & 78 \% \\ \text { McCoy } & 93 \% \\ \text { Otto } & 63 \% \\ \text { Peck } & 67 \% \\ \text { Perry } & 81 \% \\ \text { Priestley } & 78 \% \\ \text { Roberts M. } & 86 \% \\ \text { Mean } & 79 \% \\ \text { Mean for all D's } 72 \% \\ \text { Median }\end{array}$

(*Difference of mean significant as a sample at the 5\% level.) 
Women Legislators

There were eleven women in the Oregon Legislature in the 57th Session. Nine were in the House and two were in the senate. $V$ The popular conception of women in Oregon politics is that they are more liberal. Examining their partisan scores in Table XI seems to confirm this. The two women in the Senate were both Democrats. Their average partisan score was $83.5 \%$ as compared to $74 \%$ for Democrats as a whole. Democratic women in the House were also more partisan, 85\% as compared to $72 \%$ for Democrats as a whole. Republican women in the House were 26\% less partisan than Republicans as a whole; they had an average partisan score of $49 \%$ as opposed to $75 \%$ for Republicans as a whole. It should also be noted that six out of the eleven women were classified as urban legislators.

TABLE XI

PARTISANSHIP OF WOMEN IEGISIATORS

FOR THE 57TH SESSION

SENATE

Democrats

Browne $82 \%$

Roberts B. $85 \%$

Mean $83.5 \%$

Mean for all D's $74 \%$

Median $83.5 \%$ 
HOUSE

Democrats

Dereli

Fadeley N.

Katz

Peck

Roberts M.

Whiting

Mean

Mean for all D's

Median

(*Difference of means significant as a sample at 5\% leve1.)
Republicans

Burrows $\quad 54 \%$

Paulus $56 \%$

Rieke $\quad 38 \%$

Mean $49 \%$

Mean for all R's $75 \%$

Median $54 \%$

Legislators Under Thirty

There were eleven legislators under the age of thirty in the 57th Session; they were all representatives. Young office holders are also supposed to be more "liberal." If the necessary association between Democratic and liberal can again be made, we can see by examining Table XII that the opposite was true in the 57th Session. The Democratic legislators under thirty were less partisan than Democrats as a.whole. They had an average. partisan score of $61 \%$, as opposed to $72 \%$. Young Republican legislators were more partisan than Republicans as a whole, $84 \%$ to $75 \%$.

The average figure of $61 \%$ for the young Democrats is deceptive because it reflects the voting of Gilmour, Magruder and $\mathrm{C}$. Wolfer to a great extent. The median of this group is $83 \%$. The median gives information as to the 
nature of data and is that score which falls in the middle if all the scores are arranged in order of magnitude. The median in this case shows us that while the group, as a group, performed in a certain way, the majority of its members performed in another. The difference between the median of $83 \%$ and the mean of $61 \%$ only further illustrates how extreme was the behavior of these three young Democrats.

The lowest paxtisan score for any legislator duxing the two sessions studied was made by Magruder. He voted with his own party only $12 \%$ of the time. He comes from a heavily Democratic district and was unopposed in the last general election. Magruder appears to be an exception to any general rule of constituency influence. His performance is very contrary to MacRae's finding that party regulars tend to come from safe districts. This only further illustrates the risk of generalizing about something which is an extremely complex phenomenon. 
TÁBLE XII

PARTISANSHIP OF LEGISLATORS UNDER 30 YEARS OF AGE FOR THE 57TH SESSION

Democrats

AuCoin

Blumenauer

Densmore

Gilmour

Magruder

Marx

Roberts $M$.

Wolfer $C$.

Mean

Mean for all D's

Median
Republicans

Bunn $79 \%$

Johnson L. $\quad 86 \%$

Stults $D$. $\quad 86 \%$

Mean $84 \%$ *

Mean for all R's $75 \%$

Median $86 \%$

(*Difference in mean significant as a sample to $5 \%$ level.)

Freshmen Legislators

There were twenty-six freshmen legislators in the House in the 57th session. There were no freshmen in the senate. The indices of partisanship are set forth in Table XIII. Freshmen Democrats had an average partisan score of $74 \%$ versus $72 \%$ for Democrats as a whole. Freshmen Republicans had an average partisan score of $79 \%$, as opposed to $75 \%$ for Republicans as a whole.

The only notable difference between freshmen and legislators as a whole was found between the Republicans and the freshmen Republicans. Freshmen were also supposed to be more liberal than veteran legislators. This did not prove to be true. 
TABLE XIII

PARTISANSHIP OF FRESHMEN IEGISIAATORS

FOR THE 57TH SESSION

Democrats

Blumenauer

Dereli

Gilmour

Grannel1

Groener

Rafoury

Katz

Lindquist

Marx

MCCOY

Otto

Roberts $M$.

Stevenson $\mathrm{E}$.

Whalion

Whiting

Wolfer $C$.

Mean

Mean for all D's

Median
Republicans

Bunn - $79 \%$

Burrows $\quad 54 \%$

Hampton $77 \%$

Jones $91 \%$

Morris $86 \%$

Oakes $84 \%$

Stults D. $\quad 88 \%$

Whitehead $66 \%$

Wilhelms 85응

Mean $79 \%$.

Mean fọr all R's $75 \%$

Median $85 \%$

$74 \%$

$72 \%$

$82 \%$

(*Difference in means as a sample significant to $5 \%$ level.)

Change in Partisanship Due to Election From Single Member Districts

Multimember districts were eliminated in the 1971

redistricting. The supposed effect of this was to increase the influence of constituencies upon the legislators.

Each legislator would have an identifiable district and constituency due to the redistricting. Table XIV compares the average partisan scores of legislators elected from multimember districts in the 56 th Session with the average partisan scores of the same legislators elected from single member districts in the 57 th session. 
The greatest significant change seems to be in the partisanship of the three House Republicans who were elected from multimember districts in the 56th session and from single member districts in the 57th session. They had an average partisan score of $56 \%$ in the 56th session and $49 \%$ in the 57 th Session. All three of these Republican representatives were from the Portland area. They were elected from districts with Democratic majorities. This would seem to indicate that constituency influence did increase with election from single member districts.

Comparisons between other groups of legislators reveals no significant change.

TABLE XIV

COMPARISON OF PARTISANSHIP OF IEGISLATORS REPRESENTING MULTIMEMBER DISTRICTS

IN THE 56TH SESSION AND SINGLE

MEMBER DISTRICTS IN THE

$57 T H$ SESSION

\section{SENATE}

Republicans - 56th Session

Carson

Eivers

Wingard

Mean

Median
70 웅

$76 \%$

$55 \%$

$67 \%$

$70 \%$
Republicans - 57th Session

Carson

Eivers

wingard

Mean

Median $700^{\circ}$

$74 \%$

$64 \%$

$64 \%$

$70 \%$ 
Democrats - 56th Session

Browne

Burbidge

Cook*

Fadeley $E$.

Groener

Mahoney*

Roberts $B$.

Mean

Median

* Senators who ran in 1972
Democrats - 57th Session

Browne $82 \%$

Burbidge. $90 \%$

Cook $80 \%$

Fadeley E. $\quad 79 \%$

Groener $80 \%$.

Mahoney - $67 \%$

Roberts B. $85 \%$

Mean $81 \%$

Median $80 \%$

\section{HOUSE}

Republicans -56 th Session

Elliot

Kinsey

Rieke

Mean

Median

Democrats - 56 th Session

Akeson

Aucoin

Eymann

Fadeley $\mathrm{N}$.

Lang

Peck

Skelton

willits

Mean

Median
$41 \%$

$64 \%$

$61 \%$

$56 \%$

$61 \%$

$86 \%$

$81 \%$

$97 \%$

$95 \%$

$67 \%$

80 웅

$89 \%$

$85 \%$

$82 \%$

85.5 응
Republicans - 57 th Session

Elliot

$50 \%$

Kinsey

Rieke

49 웅

38 웅

Mean

$49 \% *$

Median

$49 \%$

Democrats - 57 th Session

Akeson

$75 \%$

Aucoin

$91 \%$

Eymann

87 응

Fadeley $N$.

Iang

Peck

skelton

Willits

$95 \%$

78 웅

$67 \%$

$67 \%$

75 응

Mean

$79 \%$

$76.5 \%$

*Difference of means significant as sample to $5 \%$ level. 
CHAPTER VI

CONCIUS IONS

Several conclusions can be made about partisanship and roll call voting in the oregon Legislature.

1. Few of the many issues become partisan. This partly reflects the complexity of the legislative process, which tends to resolve conflicts before measures reach the floor. It also reflects the fact that other factors and attitudes besides partisanship are involved in determining how legislators vote.

2. The minority party does tend to be more cohesive. The folk wisdom of Oregon politics was that the Republicans are more cohesive. Although this was the case in three out of the four instances examined, a generalization woüld be unjustified.

3. Urban Republicans tend to vote with Democrats. This finding confirms the folk wisdom about urban Republi-cans. It should be noted, however, that in many instances the defections of the urban Republicans only serve to balance the defection of some of the less partisan Democrats. This again illustrates that party is only one factor in the process.

4. Young legislators tend to be more partisan if they are Republicans and less partisan if they are Democrats. As mentioned earlier, this denies the popular conception of young elected officials being more liberal. 
As a group, young Democrats reduced the overall cohesiveness of the party as a whole. Although this was the result of the voting patterns of only three out of the eight young Democrats, the conclusion must be accepted because it reflects the actual behavior of the population considered.

5. Women tend to be less partisan if they are Republicans and more partisan if they are Democrats. This confirms the political folk wisdom of women being more liberal.

6. Election from single member districts seems to affect the partisanship of urban Republicans: they become less partisan. The folk wisdom states that single member districting would make legislators more receptive to constituency demand. The findings support this view, but only in a limited sense. The examination was made over a two-session period and a change in party control. Most of the conclusions found in this study were consistent with the previously mentioned works by Grumm. and MacRae. Grumm found that Republicans elected from urban Democratic areas tended to vote with the Democrats. MacRae found the same effect. He also found the reverse was true, Dernocrats elected. from Republican districts tended to vote with the Republicans. In Oregon, there are no Democratic legislators elected from districts with Republican majorities. 
It is especially hard to separate the roles of urbanization and dominant Democratic registration. As stated earlier, Republicans elected from such districts tend to vote with the Democrats. The problem is one of multiple cause. Do they vote a particular way because they are defending urban interests or because they perceive their constituency as being Democratic? As stated earlier, the change in partisanship for those urban Republicans between the 56th and 57th Sessions. would suggest the latter. The topic is complex and deserves further research which would take into account other factors such as the influence of the legislative leadership and the types of legislation considered.

As was mentioned in Chapter III, three of the areas of interest were not constituency related-women legislators, young legislators and freshmen legislators. Two of these factors, sex and youth, proved to be significant. Women were atypical in both parties in relation to partisanship. Young Democrats were also atypical.

A possible explanation of the behavior of some of the young Democrats may be constituency related. The three young representatives who had extremely low partisan scores were all from nonurban districts. There may have been other factors involved. The motivation of legislators under thirty would merit further investigation. 
In reference to women, the situation is rather complex. It was noted that there is a high correlation between election as a woman and election from an urban district. This is only one of several possibilities. one possible area of investigation might be to find some commonality in how women in oregon become involved in politics. A second possibility might be that women are the only major group in oregon politics which has what could be called a "minority" constituency. Do women legislators perceive a special concern because they are women? One measure which was sponsored only by the eleven women legislators did not undergo a party vote in either the House or the Senate. SB 148, which is now law, made men equally ä guilty of prostitution for offering to pay for such services.

Regardless, the question of constituency influence on legislators, or even influence per se is extremely intricate. The point is best made by wayne shannon in his discussion of constituency and its relation to voting patterns.

Therefore, although it would serve the purpose of neatness and theoretical nicety to be able to argue that constituency differences account for intraparty voting differences, evidence from the studies of Turner, MacRae, Forman, and the present author indicate only some relationship at some times between constituency characteristics and intraparty differences. 26

26 Wayne shannon, Party, Constituency and Congressional Voting (Baton Rouge: Louisiana State University Press, 1968), p. .155 . 
Finally, partisanship will continue to play a role in the struggle for control of the Oregon Legislature. 'The degree of partisanship of the two parties engaged in that struggle will, to a large degree, determine which will prevail. Partisanship, or cohesion, will be especially important to any majority party which holds only a small edge. The threat of coalition will be in inverse proportion to the partisanship of such a majority, for the minority party partisanship will also remain an important ingredient. A minority party with a high degree of cohesion may, in many instances, exert influence far beyond its actual size.

The legislative process is as complicated and diverse as the society for which it seeks to enact laws. It is only hoped that this study has shed some light on that process. 


\section{Bibliography}

Blalock, Hubert M. Jr. Social Statistics. New York: McGraw-Hil1, 1960.

Bodine, Harry. "Senate Chooses John Burns As President." The Oregonian, 23 Jan. 1971, p. 1, cols. 1-2.

Grumm, John G. "A Factor Analysis of Legislative

+. Behavior." Midwest Journal of Political Science, No. 7, Nov. 1968, p. 336 .

Lowell, Lawrence A. "The Influence of Party Upon Legislation in England and America." Annual Report of the American Historical Association, 1901.

Mackae, Duncan. Dimensions of Congressional Voting. Berkeley: University of California Press, 1952.

Macrae, Duncan. Issues and Parties in Legislative Voting. New York: Harper \& Row, 1970.

MacRae, Duncan. "The Relationship Between Roll Call Votes and Constituencies in the Massachusetts House of Representatives." 'American Political Science Review, No. 7, 1951, p. 1046 .

"Party Unity: Sharp Decline in 1972 Session." Congressional Roll Call. Washington, D. C.: Congrẹsitional Quarterly, 1973.

Shannon, Wayne. Party, Constituency and Congressional Voting. Baton Rouge: Louisiana state University Press, 1968.

Truman, David B. The Congressional Party. New York: John Wiley and Sons, 1959.

Turner, Julius. Party and Constituency Pressures on Congress. Baltimore: John Hopkins Press, 1951. 